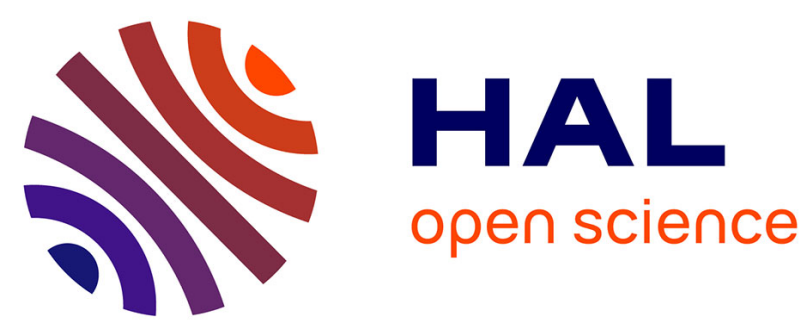

\title{
Partial overlap of fungal communities associated with nettle and poplar roots when co-occurring at a trace metal contaminated site
}

Loïc Yung, Coralie Bertheau, Flavien Tafforeau, Cyril Zappelini, Benoit Valot, François Maillard, Marc-André Selosse, Chloé Viotti, Philippe Binet, Geneviève Chiapusio, et al.

\section{To cite this version:}

Loïc Yung, Coralie Bertheau, Flavien Tafforeau, Cyril Zappelini, Benoit Valot, et al.. Partial overlap of fungal communities associated with nettle and poplar roots when co-occurring at a trace metal contaminated site. Science of the Total Environment, 2021, 782, 10.1016/j.scitotenv.2021.146692 . hal-03192784

\section{HAL Id: hal-03192784 \\ https://hal.science/hal-03192784}

Submitted on 5 Jan 2022

HAL is a multi-disciplinary open access archive for the deposit and dissemination of scientific research documents, whether they are published or not. The documents may come from teaching and research institutions in France or abroad, or from public or private research centers.
L'archive ouverte pluridisciplinaire $\mathbf{H A L}$, est destinée au dépôt et à la diffusion de documents scientifiques de niveau recherche, publiés ou non, émanant des établissements d'enseignement et de recherche français ou étrangers, des laboratoires publics ou privés.

\section{(ㅇ)(1) $\$$}

Distributed under a Creative Commons Attribution - NonCommercial - NoDerivatives| 4.0 

4

\section{Partial overlap of fungal communities associated with nettle and poplar roots when co-occurring at a trace metal contaminated site}

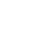

Loïc Yung ${ }^{1, a, b}$, Coralie Bertheau ${ }^{1}$, Flavien Tafforeau ${ }^{1}$, Cyril Zappelini ${ }^{1 c}$, Benoit Valot ${ }^{1}$, François Maillard ${ }^{1, \mathrm{~d}}$, Marc-André Selosse ${ }^{2,3,}$, Chloé Viotti $^{1}$, Philippe Binet ${ }^{1}$, Geneviève 6 Chiapusio $^{1, \mathrm{e}}$, Michel Chalot ${ }^{1,4}$ 7

${ }^{1}$ Chrono-environnement UMR6249, CNRS, Université Bourgogne Franche-Comté, F-25000, Besançon, France

${ }^{2}$ Institut de Systématique, Evolution, Biodiversite (ISYEB - UMR 7205 - CNRS, MNHN, SU, EPHE), Muséeum national d'Histoire naturelle, 75000 Paris, France

${ }^{3}$ Faculty of Biology, University of Gdan sk, ul. Wita Stwosza 59, 80-308 Gdansk, Poland

${ }^{4}$ Université de Lorraine, Faculté des Sciences et Technologies, 54000 Nancy, France

Corresponding author: Loïc Yung, Université de Lorraine, Boulevard des Aiguillettes - BP 70239, F-54506 Vandoeuvre-les-Nancy Cedex, France. loic.yung@univ-lorraine.fr

Current addresses :

${ }^{a}$ Université de Lorraine, CNRS, LIEC, 54000 Nancy, France

${ }^{b}$ Université de Lorraine, INRAE, LSE, 54000 Nancy, France

${ }^{c}$ French National Institute for Agricultural Research, INRAE. Department of Agroecology, 21000 Dijon, France

${ }^{d}$ Department of Plant \& Microbial Biology, University of Minnesota, St. Paul, MN, USA

${ }^{e}$ Laboratoire Carrtel, Université Savoie Mont Blanc INRAE 042, Domaine Universitaire Belledonne, 73370 Le Bourget-du-Lac, France 


\section{Summary}

Stinging nettle (Urtica dioica L.) raises growing interest in phytomanagement because it commonly grows under poplar Short Rotation Coppices (SRC) set up at trace-metal (TM) contaminated sites and provides high-quality herbaceous fibres. The mycobiome of this nonmycorhizal plant and its capacity to adapt to TM-contaminated environments remains unknown. This study aimed at characterizing the mycobiome associated with nettle and poplar roots co-occurring at a TM-contaminated site. Plant root barcoding using the fungi-specific ITS1F-ITS2 primers and Illumina MiSeq technology revealed that nettle and poplar had distinct root fungal communities. The nettle mycobiome was dominated by Pezizomycetes from known endophytic taxa and from the supposedly saprotrophic genus Kotlabaea (which was the most abundant). Several ectomycorrhizal fungi such as Inocybe (Agaricomycetes) and Tuber (Pezizomycetes) species were associated with the poplar roots. Most of the Pezizomycetes taxa were present in the highly TM-contaminated area whereas Agaricomycetes tended to be reduced. Despite being a known non-mycorrhizal plant, nettle was associated with a significant proportion of ectomycorrhizal OTU (9.7\%), suggesting some connexions between the poplar and the nettle root mycobiomes. Finally, our study raised the interest in reconsidering the fungal networking beyond known mycorrhizal interactions.

\section{Keywords}

Ectomycorrhizal fungi ; Environmental metabarcoding ; Fungal network ; Metal-enriched sediments ; Phytomanagement ; Root-associated mycobiome ; Urtica dioica L.. 


\section{Introduction}

Phytomanagement is a remediation technique based on plant species to restore and revalorize polluted sites while producing biomass (Cundy et al., 2016; Evangelou et al., 2015). Fast-growing trees such as poplars (Populus sp.) allow the production of a high amount of valuable plant biomass for renewable energy (Kidd et al., 2015; Pandey et al., 2016). At the same time, trees limit the dispersal and risks of soil contaminants, while promoting the spontaneous biodiversity (Parraga-Aguado et al., 2014). Recent approaches on the optimisation of phytomanagement systems pointed out the importance of assemblages between crops and spontaneous species (Parraga-Aguado et al., 2013) to ensure a more efficient and gentle remediation (Boisson et al., 2016). The spontaneous vegetation biodiversity is generally restricted by the soil physico-chemical properties, limiting the panel of species able to develop and compete with the tolerant species (Macnair, 1987). Much less is known on how this plant biodiversity is shaping its root microbiota in this context.

The stinging nettle (Urtica dioica L.) colonizes a vast diversity of nitrophilic environments and particularly anthropogenic areas (Balabanova et al., 2015; Shams et al., 2010; Viktorova et al., 2016). It has thus been frequently observed as a companion species in a wide range of nitrogen-rich environments such as Salicaceous plantations at both natural (Cronk et al., 2016) and anthropized sites (Yung et al., 2019). Nettle has recently raised growing interest in the domain of phytomanagement because it (i) constitutes a new resource of high-quality herbaceous fibres for the manufacture of biomaterials (Bacci et al., 2009; Di Virgilio et al., 2015; Jeannin et al., 2019, 2020), (ii) promotes the biodiversity of local entomofauna (James et al., 2015; Perrin, 1975; Yung et al., 2019) and (iii) spontaneously grows in contaminated sites (Murtic et al., 2019; Paukszto and Mirosławski, 2019; Viktorova et al., 2016).

The success of phytomanagement depends on the capacity of plants to colonize harsh environments, which is partly related to their ability to interact with soil microorganisms, and 
especially to establish symbiotic relationships with some of them. Among these microorganisms, arbuscular mycorrhizal (AM) (Miransari, 2017), ectomycorrhizal (EM) (GilMartínez et al., 2018) fungi and Dark Septate Endophytes (DSE) (Deng and Cao, 2017) are major drivers of plant growth and response to abiotic stress and phytopathogens (Otero-Blanca et al., 2018; Selosse et al., 2004). The use of fungal inoculum has been described as a phytoremediation enhancer by improving uptake and accumulation of trace metals (TM) by plants in phytoextraction application or by limiting the translocation of TM from roots to shoots during phytostabilisation (Berthelot et al., 2016a; Khan, 2005; Ma et al., 2019; Pepper et al., 2015). While the success of field inoculation is rather unpredictable (Gerhardt et al., 2017; Selosse et al., 1998, 1999) due to various abiotic (e.g., sensitivity to TM) and biotic parameters (e.g., competition with the local microbiome), the risks of failure may be mitigated by considering indigenous strains, which may have developed a tolerance for TM (Wubs et al., 2016). Characterisation of in-situ plant-associated microbiome appears as an essential preliminary step for identifying rhizospheric microorganisms that may actively participate to phytomanagement processes.

In the temperate climate zone, poplars are among the few cultivated trees that form tripartite symbiotic associations with EM and AM fungi (Gehring et al., 2006; Teste et al., 2020). As symbiotic fungi play crucial roles in soil fertility, colonisation, plant nutrition, metal uptake, accumulation or restriction in plants (Smith and Read, 2010; van der Heijden et al., 2015), poplar microbiome have been well studied in phytomanagement contexts (Durand et al., 2017; Foulon et al., 2016b; Schmidt et al., 2018; Vitali et al., 2019; Zappelini et al., 2015). Recent studies highlighted the positive effects of EM and AM inoculation on poplar cultivars growing at a multi-contaminated site (Ciadamidaro et al., 2017; Phanthavongsa et al., 2017). However, mycobiome associated with nettle have been barely studied in natural or anthropogenic biota. A study combining in-situ and mesocosm approaches concluded that the 
nettle rhizosphere was devoid of any mycorrhizal structures and revealed that the AM fungus Glomus mosseae was not able to develop in the presence of nettle (Vierheilig et al., 1996). The authors speculated that a rhizome protein called Urtica dioica agglutinin (UDA) with antifungal properties (Broekaert et al., 1989) could be involved in AM avoidance. In addition, this inhibitory effect could even affect the mycobiome of neighbouring plants (Fontenla et al., 1999).

The present study aimed at characterizing, using Illumina Mi-seq sequencing, the mycobiome associated with nettle and poplar roots co-occurring in an agrosystem set up on a contaminated site, where two areas were clearly distinguished by their TM concentrations. We hypothesised that poplar and nettle would harbour distinct root-associated fungal communities: poplar mycobiome would be dominated by EM and AM fungi; at the opposite, nettle communities would be composed of endophytic fungi (i.e. fungi colonizing root tissues asymptomatically (Wilson, 1995)) with a low fungal diversity as described above. We further hypothesised that the level of TM contamination would alter the root-associated mycobiomes by reducing root fungal diversity and by increasing the diversity and abundance of TM-tolerant fungi, as mentioned elsewhere (Giller et al., 2009; Zappelini et al., 2015).

\section{Material and methods}

\subsection{Site description}

The study site located at Fresnes-sur-Escaut (France, 50²5'47.9"N $3^{\circ} 35^{\prime} 07.8^{\prime \prime} \mathrm{E}$ ) is a nettle-poplar agrosystem on a dredged sediment disposal site, contaminated with TM, that operated between 1978 and 1989.

Approximately $200000 \mathrm{~m}^{3}$ of silt and sand from the dredging of l'Escaut canal were deposited, resulting in heterogeneous contamination with $\mathrm{As}, \mathrm{Cd}, \mathrm{Cu}, \mathrm{Ni}, \mathrm{Pb}$ and $\mathrm{Zn}$ within the surface horizons $(0-50 \mathrm{~cm})$. The experimental site is divided into two areas differing by the level of TM: the low trace-metal (LTM) and the high trace-metal (HTM) areas. The HTM area 
118 has mean soil concentrations of $\mathrm{Zn}(2231 \mathrm{mg} / \mathrm{kg}), \mathrm{Pb}(425 \mathrm{mg} / \mathrm{kg}), \mathrm{Cu}(108 \mathrm{mg} / \mathrm{kg})$ and $\mathrm{Cd}(63$

$119 \mathrm{mg} / \mathrm{kg}$ ), on average 20-, 9-, 4- and 100-fold higher than the LTM area, respectively

120 (Phanthavongsa et al., 2017). A phytomanagement field trial was implemented in 2011 on this

121 site (covering both areas) with plots of poplar Skado (P. trichocarpa $\times$ P. maximowiczii) or

$122 \mathrm{I} 214$ (P. deltoides $x$ P. nigra) as a short-rotation coppice (SRC; 2200 stems/ha). A detailed

123 description of the experimental design is provided in Ciadamidaro et al., (2017) and

124 Phanthavongsa et al., (2017). Five years after planting, the spontaneous herbaceous layer evolved in the same way as that of another similar experiment set up in eastern France, with a dominance of the stinging nettle under poplars with a coverage rate depending on the poplar cultivar (Yung et al., 2019). In order to get rid of this variable and appreciate the contaminant

128 effect on the microbiomes associated with nettle and poplar roots, we selected only one plot for each poplar cultivar (i.e. Skado or I214) for both the HTM and LTM areas, each of $504 \mathrm{~m}^{2}(28 \mathrm{~m}$ $\mathrm{x} 18 \mathrm{~m}$ ), i.e. 4 plots in all. These plots are of sufficient size to allow for replicate collection.

\subsection{Sample collection and preparation}

The sampling was conducted in November 2016, consisting of root samples from the upper 20-cm layer of soil from 9 random poplars and 9 adjacent nettles for each of the four studied plots. Comparisons between soil and poplar root mycobiomes were done and available in our previous studies (Durand et al., 2017; Foulon et al., 2016b, 2016a). A total of three pseudo-replicates of thin roots were sampled from each tree and mixed to obtain one composite per poplar individual, whereas the entire root system of nettles was collected. For each plant,

138 the root samples were carefully sorted so as not to be mixed, the soil was carefully removed in

139 three successive baths in sterilized distilled-water, and the smallest roots were selected and 140 separated from larger roots by sampling them with a scalpel. The samples were freeze-dried 141 and stored at $-20^{\circ} \mathrm{C}$ before molecular analysis. Thus, we considered both the endophytic and 142 epiphytic fungi from the rhizoplane. 
145 isolation Kit following the manufacturer's instructions (MoBio Laboratories, Inc., Carlsbad,

146 CA, USA). The PCR was performed using the specific fungal primers ITS1F (5'-

148 (Gardes and Bruns, 1993; White et al., 1990). We selected these primers to allow for

149 comparison with our previous dataset obtained on a similar plantation, at a different site

150 (Durand et al., 2017). These primers has also been found as one of the most competent in

151 uncovering the fungal diversity of plant root (Bainard et al., 2017; Huang et al., 2020). PCR

152 was performed in a reaction volume of $35 \mu \mathrm{L}$ using $0.5 \mu \mathrm{M}$ forward and reverse primer each,

$153200 \mu \mathrm{M}$ dNTPs, $1 \mu \mathrm{L}$ of Phire hot start II DNA polymerase $(1 \mathrm{U} / \mu \mathrm{l}), 26.25 \mu \mathrm{L}$ of $5 \mathrm{X}$ Phire

154 reaction buffer (Thermo Fisher Scientific, Inc. USA), $10 \mathrm{ng}$ template DNA and sterilized water

155 to reach a final volume of $35 \mu$. The PCR conditions were $98^{\circ} \mathrm{C}$ for $30 \mathrm{sec}$, followed by 25

156 cycles of $98^{\circ} \mathrm{C}$ for $5 \mathrm{sec}, 57.2^{\circ} \mathrm{C}$ for $5 \mathrm{sec}$ and $72{ }^{\circ} \mathrm{C}$ for $15 \mathrm{sec}$, followed by a final extension step at $72{ }^{\circ} \mathrm{C}$ for $1 \mathrm{~min}$. These primers targeted a short portion of the fungal ITS region, resulting in amplicons of small size ( $\sim 300 \mathrm{bp})$, appropriated for Illumina sequencing. The DNA quality and quantity were assessed by agarose gel electrophoresis using the ImageLab software (Bio-

160 Rad, USA) and with a Qubit ${ }^{\mathrm{TM}}$ dsDNA HS Assay Kit (Invitrogen, Carlsbad, CA, USA) using 161 the Qubit 4 fluorometer. The partial fungal ITS region (Wang et al., 2015) of 6 and 7 of nine poplar and nettle samples (i.e. with the concentration of environmental DNA required) were sequenced with the Illumina MiSeq platform (Microsynth AG, Switzerland).

\subsection{Bioinformatic analysis}

The sequence data were processed using Mothur (Schloss et al., 2009). First, all raw read pairs were joined at the overlapping region to create consensus sequences. Then several steps of filtering were performed, consisting in removing homopolymers, ambiguous sequences and sequences with an inappropriate length (shorter than $220 \mathrm{bp}$ and greater than $400 \mathrm{bp}$ ). The 18S RNA region amplified by the ITS1F primer (Toju et al., 2012) was removed by in-silico 
170 PCR to target precisely the ITS1 region. After quality filtering, reads were then clustered into

171 OTUs using the swarm tools (Mahé et al., 2015) with a difference value of 1 and fastidious

172 option enable. The OTU clustering method has been repeatedly shown to be powerful for

173 recovering the richness and composition of the fungal community (Bell et al. 2014; Durand et

174 al., 2017; Foulon et al., 2016b; Huang et al. 2020; Nguyen et al., 2016). We removed singleton

175 OTUs to avoid technical artefacts and overestimation of the number of species (Tedersoo et al.,

176 2010). The taxonomic assignment of OTUs was performed using the UNITE (Kõljalg et al.,

177 2013) database by a naïve Bayesian approach (Wang et al., 2007).The presence of plant

178 sequences was verified using the BLAST tool of the GenBank database and removed. Each

179 fungal OTU was further assigned to functional or morphological groups of fungi using

180 FUNguild (Nguyen et al., 2016). For each assignment, three confidence rankings (i.e.,

181 "possible": suspected, "probable": fairly certain, "highly probable": absolutely certain)

182 referring to previously peer reviewed data were given. We only considered the functional and

183 morphological assignation with at least a "probable" confidence ranking. Finally, the guilds

184 related to a similar function were grouped to obtain a total of six main guilds, based on the

185 literature.

186

\subsection{Data analysis}

Alpha diversity indices (OTU richness, Chao estimation, Shannon diversity index, inverse of the Simpson diversity index) were calculated using MOTHUR. Samples were rarefied at 33000 sequences, corresponding to the smallest number of sequences detected in a sample. No sample was excluded. To verify that sequencing depth allowed covering most of the fungal diversity of our root samples, Good's coverage was calculated as $C=[1-(n / N)] \times$ $100(\%)$, where " $\mathrm{n}$ " is the number of OTUs, and " $\mathrm{N}$ " is the number of sequences (Good, 1953). Statistical analyses were performed with R software v.3.6.1 (R Development Core Team, 2019). All the considered variables were tested for their homoscedasticity (Bartlett or Levene tests) and normal distribution (Shapiro-Wilk test) and compared using analysis of 
variance (ANOVA) followed by a Tukey HSD test. Where necessary, data were "log"

197 transformed to improve normality. Data that did not fit a normal distribution after

198 transformation were analysed with non-parametrical tests (Kruskal-Wallis test by ranks). First

199 we calculated and drew rarefaction curves for each experimental condition of nettle and poplar,

200 using "rarecurve" function available in the R Vegan package. The shape of the curve is a graphic

201 display of the relative estimated species accumulation rates. All diversity and richness indices

202 and the mean number of OTUs were then compared between all experimental conditions and

203 plants through ANOVA followed by a Tukey HSD test.

To summarize differences in fungal OTU composition between the experimental

conditions for both the I214 and Skado plots, we used two-dimensional non-metric Multi-

206 Dimensional Scaling (NMDS) plots based on Bray-Curtis dissimilarity matrix $(k=2)$ using the

207 metaMDS function of the R Vegan package. Permutational multivariate analyses of variance

208 (PERMANOVA) based on Bray-Curtis dissimilarity were applied to determine the potential

209 effects of the plant species (nettle $v s$ poplar) and the level of contamination (LTM vs HTM) on

210 fungal communities for both I214 and Skado plots. To assess the influence of the studied factors

211 on the fungal classes, genera, EM fungal taxa and guilds, the experimental conditions were

212 compared using a Kruskal-Wallis test, followed by a post-hoc test with a Holm correction of 213 the p-value.

214 NMDS and PERMANOVA analyses were further performed on the EM fungal guilds.

215 For the whole fungal community and the six most abundant guilds taken individually, for nettle

216 and poplar, we tested the correlation and the overlapping between the OTU composition using

217 Mantel test (ade4 package) and by calculating the Morisita-Horn similaritity index (SpadeR

218 package), respectively. The relative abundances of EM fungal OTUs were represented by a

219 heatmap, from the pheatmap R package. Similarly, a hierarchical cluster analysis of the relative 
abundances of EM fungal OTUs from the various experimental conditions was represented by

221 a dendrogram expressing the linkage between species and between the experimental conditions.

\subsection{Diversity of mycobiome associated with nettle and poplar roots}

Illumina MiSeq sequencing of ITS1 amplicons obtained from 26 root samples of poplar and 25 root samples of nettle generated a total of 3,481,223 non-chimeric fungal sequences.

The initial total number of sequences obtained per sample ranged from 33,615 to 140,409 . The

dataset.

Table 1: Results of the Illumina MiSeq sequencing of ITS1 amplicons, including richness and diversity indices of the mycobiomes associated to I214 and Skado poplar roots, or to nettle roots growing in the I214 or Skado plots, at low trace-metal (LTM) and the high trace-metal (HTM) areas. Mean values and standard deviations (mean \pm SD) are provided for each experimental condition. The "total number of sequences" corresponds to datasets before subsampling at 33,000 sequences, while the other parameters are calculated after subsampling.

238 Values designated with the same letters are not significantly different (Kruskal-Wallis test, $P$ $239<0.05)$.

\begin{tabular}{|c|c|c|c|c|c|c|c|c|}
\hline & \multicolumn{4}{|c|}{ NETTLE } & \multicolumn{4}{|c|}{ POPLAR } \\
\hline & \multicolumn{2}{|c|}{ LTM } & \multicolumn{2}{|c|}{ HTM } & \multicolumn{2}{|c|}{ LTM } & \multicolumn{2}{|c|}{ HTM } \\
\hline & I 214 & Skado & I 214 & Skado & I 214 & Skado & $\mathrm{I} 214$ & Skado \\
\hline $\begin{array}{l}\text { Number of } \\
\text { samples }\end{array}$ & 6 & 6 & 6 & 7 & 6 & 7 & 6 & 7 \\
\hline $\begin{array}{l}\text { Mean total } \\
\text { number of } \\
\text { sequences }\end{array}$ & 52,264 & 73,778 & 68,434 & 70,185 & 69,479 & 63,116 & 55,243 & 61,067 \\
\hline $\begin{array}{l}\text { Mean OTUs } \\
\text { observed }\end{array}$ & $175^{\mathrm{ab}}( \pm 56)$ & $168^{\mathrm{ab}}( \pm 69)$ & $122^{b}( \pm 23)$ & $109^{\mathrm{b}}( \pm 52)$ & $178^{\mathrm{ab}}( \pm 19)$ & $196^{\mathrm{a}}( \pm 30)$ & $156^{\mathrm{ab}}( \pm 38)$ & $204^{\mathrm{a}}( \pm 43)$ \\
\hline $\begin{array}{l}\text { Chao } \\
\text { estimation }\end{array}$ & $248^{c}( \pm 56)$ & $280^{\mathrm{bc}}( \pm 61)$ & $221^{\mathrm{c}}( \pm 25)$ & $210^{\mathrm{c}}( \pm 64)$ & $362^{\mathrm{ab}}( \pm 31)$ & $410^{\mathrm{a}}( \pm 74)$ & $232^{\mathrm{c}}( \pm 33)$ & $358^{\mathrm{ab}}( \pm 70)$ \\
\hline $\begin{array}{l}\text { Shannon } \\
\text { index }\end{array}$ & $2.3^{\mathrm{ab}}( \pm 0.8)$ & $2.7^{\mathrm{a}}( \pm 1.0)$ & $2.2^{\mathrm{ab}}( \pm 0.6)$ & $1.4^{\mathrm{b}}( \pm 1.0)$ & $2.4^{\mathrm{ab}}( \pm 0.5)$ & $2.7^{\mathrm{a}}( \pm 0.5)$ & $2.9^{\mathrm{a}}( \pm 0.7)$ & $2.9^{\mathrm{a}}( \pm 0.5)$ \\
\hline $\begin{array}{l}\text { Inverse of } \\
\text { Simpson } \\
\text { diversity } \\
\text { index }\end{array}$ & $6.0^{\mathrm{a}}( \pm 5.4)$ & $8.9^{\mathrm{a}}( \pm 6.1)$ & $5.8^{\mathrm{a}}( \pm 3.4)$ & $3.1^{\mathrm{a}}( \pm 2.8)$ & $5.7^{\mathrm{a}}( \pm 2.3)$ & $7.7^{\mathrm{a}}( \pm 5.3)$ & $10.1^{\mathrm{a}}( \pm 5.7)$ & $8.9^{\mathrm{a}}( \pm 6.1)$ \\
\hline
\end{tabular}


cover the fungal diversity of our root samples. Additionally, the measured Good's coverage

244 values were greater than $99 \%$ for each condition and in every sample, suggesting a 245 representative sampling. Rarefaction curves for nettles clearly exhibited divergent trends in 246 LTM vs. HTM areas. For a same number of reads on the asymptote, the HTM plots reached a 247 number of OTUs reduced by approximately 30\%, as compared to the LTM plots (Figure S1). 248 Concerning poplar, the curve for the I214-HTM plot was clearly lower than those corresponding 249 to the three other experimental conditions. The total number of fungal OTUs was comparable for nettle (1218) and poplar (1321). 251 Among them, nettle and poplar shared 766 OTUs, representing $63 \%$ of the total number of 252 OTUs for nettle and $58 \%$ for poplar. The mean number of fungal OTUs associated with the 253 roots of nettle and poplar are detailed in Table 1 for each experimental condition. The highest 254 mean number of OTUs was obtained for Skado roots from the HTM area, whereas the lowest 255 was obtained for nettles within the same area, with a significant difference $(\mathrm{P}<0.05)$. Only $2567.1 \%$ and $7.5 \%$ of the total number of OTUs were shared between the four conditions for nettle 257 and poplar, respectively. Additionally, the percentage of OTUs specific to each condition 258 ranged between $8.5 \%$ and $19.9 \%$ for nettle and between $11.2 \%$ and $14.8 \%$ for poplar (Figure 259 1). For nettle, this number of specific OTUs was 2-fold higher in the LTM area (35.4\%) 260 compared to the HTM area (17.3\%), whereas it was comparable for poplar (23vs 26\%). 261 Depending on the experimental condition, nettle shared between $47.3 \%$ and $63.0 \%$ of their 262 OTUs with poplar, while poplar shared between $39.5 \%$ and $44.0 \%$ of their OTUs with nettle 263 (Figure 1). 

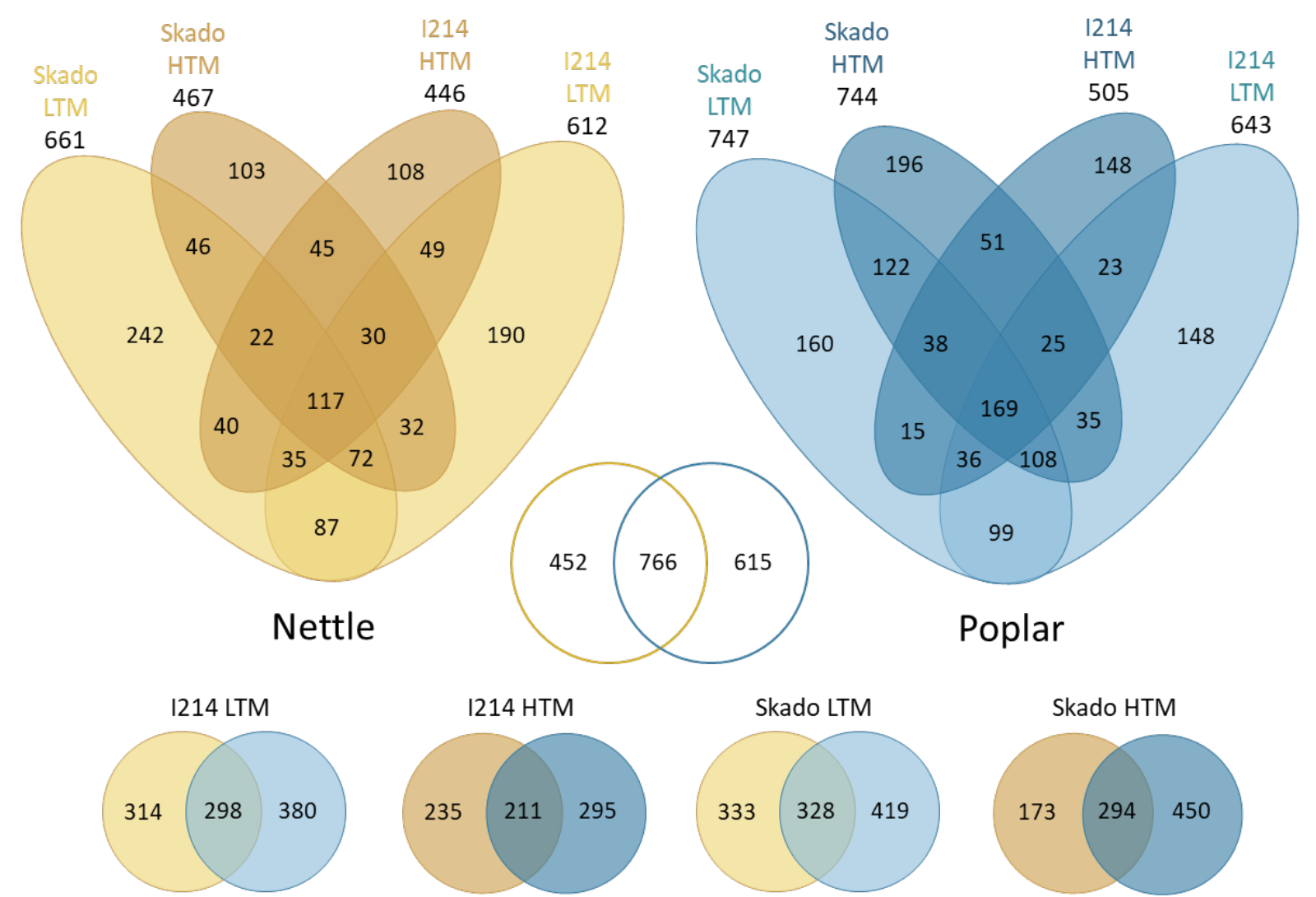

Figure 1: Venn diagrams showing the overlap of the fungal communities according to the poplar cultivar plot (I214 and Skado) and the level of TM in soil (LTM and HTM), for nettle (left) and poplar (right). These diagrams present the number of total (above the ellipses), specific (within non-intersected ellipses) and shared OTUs (intersected ellipses). The five couples of circles provide the total number of OTUs for nettle (left) and poplar (right) and the shared number (intersection) for the whole dataset (center) and for each experimental conditions (bottom).

While the obtained mean numbers of fungal OTUs were comparable between nettle and poplar, the estimated number of fungal OTUs (using the Chao model) showed a higher species richness in poplar roots, except for the I214-HTM condition (Table 1). The species richness of the HTM area was lower than the LTM area for nettle, while this tendency was only noticeable for I214 poplars, as suggested by the rarefaction curves (Figure S1). For nettle, we collected an average of $65 \%$ and $54 \%$ of the estimated number of OTUs (Chao estimation) for the LTM and HTM areas, respectively, whereas we obtained 69\% for HTM versus 48\% for LTM for poplar. Overall, when considering the individual diversity estimators related to poplar or nettle, no 281 apparent influence of the studied factors level of contamination was noticeable. However, 282 NMDS analysis revealed a clear clustering of fungal communities according to the plant species 
(nettle vs poplar) and the level of contamination (LTM vs HTM) for the I214 and Skado plots

284 (Figure 2). Thus, while the fungal diversity did not seem to be significantly influenced by the

contrasted and affected by the level of TM contamination and the plant species (Figure 2).

NMDS and PERMANOVA indicated substantial differences in the composition of fungal

288 communities between nettle and poplar (Figure 2), the plant species factor explaining $24 \%$ and

$28917 \%$ of the variance in the fungal community for I214 and Skado plots, respectively $(\mathrm{P}<0.001$;

290 Table S1). The level of TM had a significant effect on the fungal communities, both for nettle

291 grown under I214 (28\%) and Skado (37\%) and for poplar, although to a lesser extent (26\% for

292 I214, and 16\% for I214 Skado) (all P < 0.01; Figure 2, Table S1).
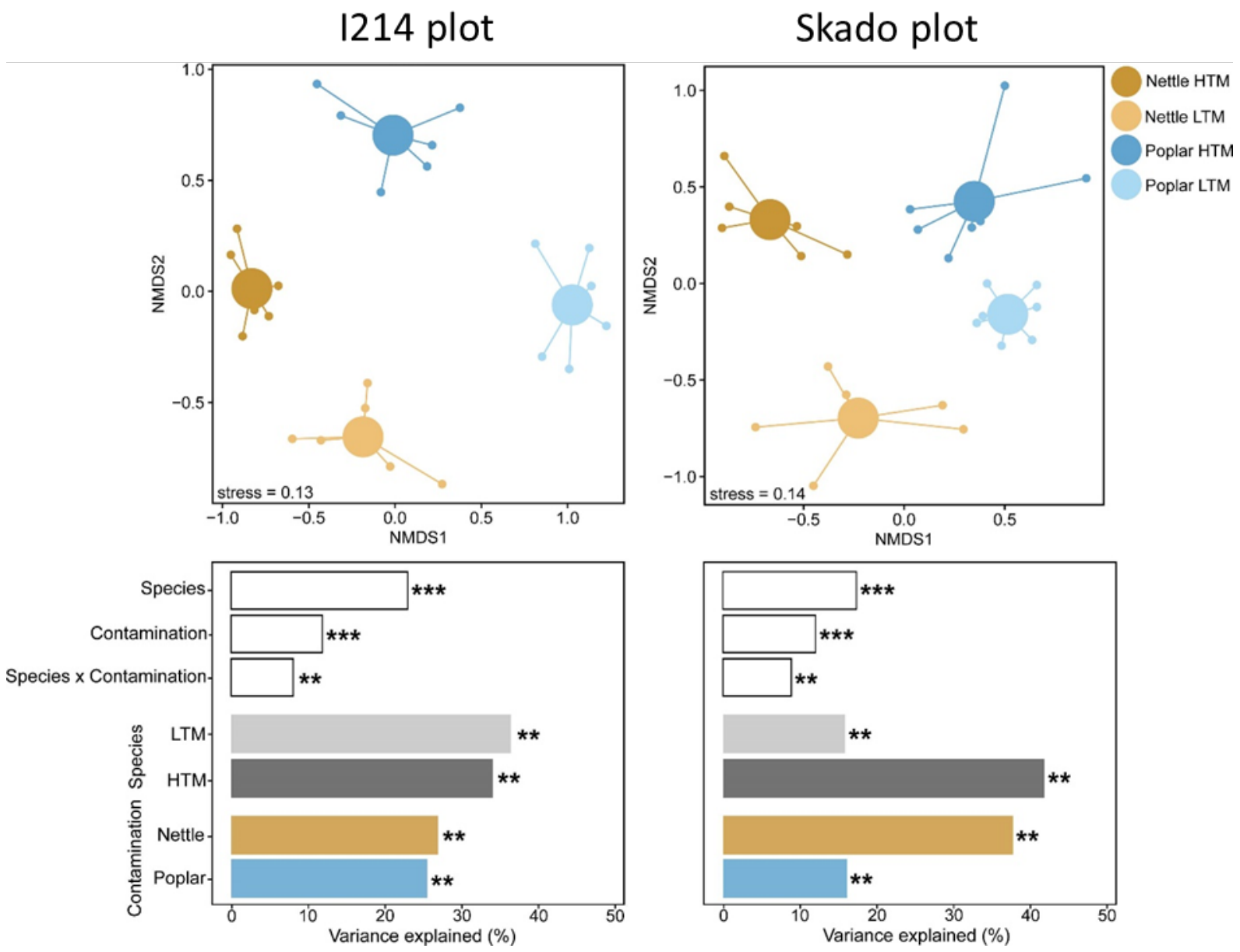

Figure 2: Non-parametric multidimensional scaling (NMDS) plot of fungal communities associated with nettles and poplars grown at LTM and HTM areas, for 1214 (left) and Skado (right) plots, using the Bray Curtis dissimilarity measure. Small and large circles represent the individual samples and the centroids of the different temperatures, respectively. Results from a 
PERMANOVA analysis for plant species ("species") and level of TM ("contamination") factors and their interaction, and conducted separately by species (contamination effect) and contamination (species effect) are provided under each NMDS, with the following legend: ***, $P<0.001 ; * *, P<0.01 ; * P<0.05$.

302

303

304

\subsection{Taxonomic characterization of the mycobiome of nettle and poplar roots}

The fungal communities associated with roots of plants growing at the sediment disposal site studied were dominated by the phylum Ascomycota in nettle roots ( $84.5 \%$ of total relative abundance) whereas Basidiomycota (43.2\%) and Ascomycota (52.3\%) were more equally represented in poplar roots (the Ascomycota/Basidiomycota ratio was significantly higher for nettle than for poplar; $\mathrm{P}<0.05)$.

Among all samples, we detected 29 and 28 distinct fungal classes for nettle and poplar, respectively. Among them, the most abundant classes were Pezizomycetes, Agaricomycetes, Leotiomycetes, Dothideomycetes, Sordariomycetes, Mortierellomycetes, Eurotiomycetes and Olpidiomycetes (total relative abundance of each $>0.5 \%$; Figure S2). For this study, Dothideomycetes and Leotiomycetes, as abundant classes, characterized the mycobiome of nettle roots. In contrast, poplar roots were characterized by Agaricomycetes, representing 20$66 \%$ of all sequences, depending on the experimental condition (Figure S2). Pezizomycetes were also well represented and similarly abundant in both plants.

For poplars, $79 \%$ of the fungal sequences were successfully assigned to a genus $(73 \%$ for I214 vs 85\% for Skado), whereas only 54\% were successfully assigned for nettle (Figure 3). The genus Kotlabaea was the most abundant genus associated in nettle roots ( $26.5 \%$ of the total number of fungi associated with nettle), followed by three unknown genera belonging to Helotiales (17.5\%), Didymosphaeriaceae (8.7\%) and Phaeosphaeriaceae (5.8\%). The genera Tetracladium (5.7\%) and Hymenoscyphus (2.5\%) were the most abundant nettle-associated Leotiomycetes and were also present in poplar roots with comparable relative abundances (Figure 3). For poplar, the most abundant genera were Inocybe (17.1\% of the total number of 
fungi associated with poplar), Tuber (10.8\%), Hebeloma (7.3\%), Tomentella (6.9\%) and Geopora (7.1\%), the latter being almost absent in nettle roots $(<0.02 \%)$ (Figure 3$)$. The genus Olpidium (Olpidiomycetes), accounting for $1.3 \%$ and $1.4 \%$ of the fungal sequences for nettle and poplar, respectively, was also well represented.

We detected significant differences in terms of fungal composition between the two poplar cultivars. Tomentella, Geopora, Hymenogaster, Hebeloma and Clavulina were more represented in roots of the Skado cultivar, while Helvella and Kotlabaea were mostly associated with 214 cultivar $(\mathrm{P}<0.05)$, but each of these trends were only significant for one of the two considered areas (i.e., LTM or HTM; P < 0.05; Figure 3, Table S2). Differences were also noticed between mycobiomes of nettles grown in I214 plots (high density of nettle) and those grown in Skado plots (low density of nettle). Inocybe, Genabea, Helvellosebacina and Hebeloma were more abundant in roots of nettles grown in the Skado plot $(\mathrm{P}<0.05)$, whereas Olpidium and Calyptella were more abundant in the $\mathrm{I} 214$ plot $(\mathrm{P}<0.05)$. These results were significant for only one of the two considered areas (Figure 3, Table S2). Pezizomycetes were significantly influenced by TM contamination : first, their relative abundance was significantly higher at the HTM area for nettles, both the I214 (10\% for LTM vs. 32\% for HTM; P < 0.05) and Skado $(7 \%$ vs. $68 \%$; $\mathrm{P}<0.05)$ plots. Second, the same trend was observed on poplar but only statistically supported for the Skado cultivar, (6\% vs. 41\%; P $<0.05$; Figure S2). Among Pezizomycetes, the genus Kotlabaea significantly increased in the HTM area (for I214 plots: 0.1\% vs. 31.7\%; for Skado plots: $2.5 \%$ vs. $65.1 \%$; $\mathrm{P}<0.05$; Figure 3). Similarly, the genus Tuber was more represented in the poplar roots collected from the HTM area (for the I214 cultivar: $6.2 \%$ vs. 17.6\%; for the Skado cultivar 4.6\% vs. 15.2\%; P), however, the high between-sample variability did not allow to statistically support this. Agaricomycetes associated with both poplar and nettle were influenced by TM as their abundance was significantly reduced in the HTM areas $(\mathrm{P}<0.05)$, except for nettle in the I214 plots (Figure S2). This reduction of 
Agaricomycetes in the HTM area was mainly due to the decrease of the Inocybe genus, the most

352 abundant of all Agaricomycetes for nettle (34\%) and poplar (40\%) (Figure 3). When considering

353 nettle and poplar together, the relative abundance of Inocybe species decreased from LTM- to

354 HTM area, namely from 31.9 to $1.5 \%$ for $\mathrm{I} 214$ plots and from 24.1 to $8.1 \%$ for Skado plots (P

$355<0.05$ in each case; Figure 3). A similar but less pronounced trend was also noticeable for the 356 genus Tomentella within the $\mathrm{I} 214$ plots.

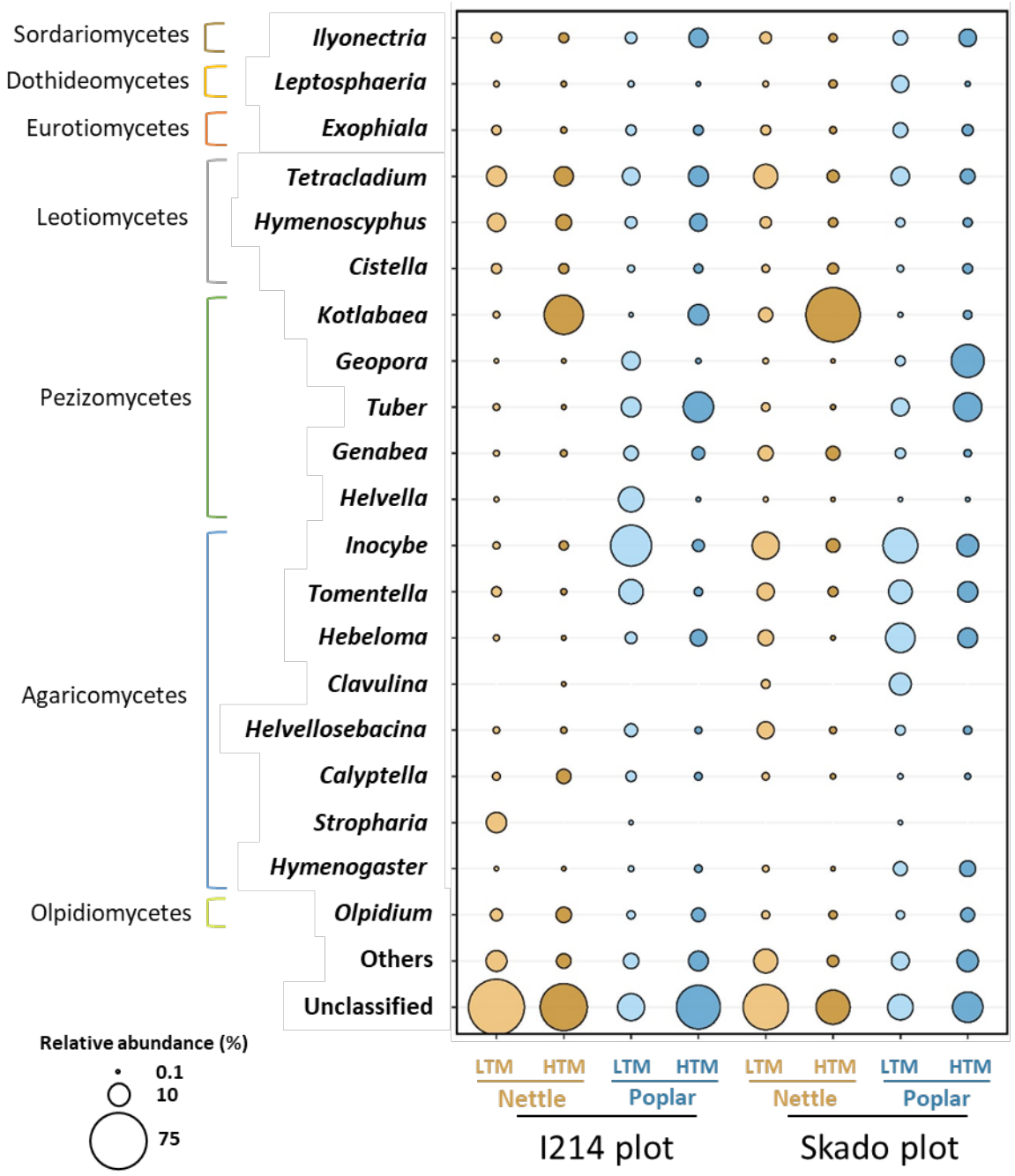

358 Figure 3: Relative abundance of the 20 most represented fungal genera (based on the 359 taxonomic assignment of OTUs), belonging to 7 classes, according to the level of TM in soil 360 (LTM and HTM) for nettle (orange bubbles) and poplar (blue bubbles) grown in the I214 or 361 Skado plots. The classes with a relative abundance $<0.5 \%$ have been gathered in the "others" 362 group. For each genus, the related results from Kruskal-Wallis pairwise or Tukey HSD tests are provided in the Table $S 2$.

\subsection{Functional characterization of the mycobiome of nettle and poplar roots}



$70.4 \%$ and $83.1 \%$, respectively, were successfully assigned to a functional guild with at least a "probable" confidence ranking using FUNguild (Nguyen et al., 2016). This functional assignment revealed a majority of saprotrophic fungi (from 18 to $69 \%$ depending on the condition), followed by plant pathogens $(6-15 \%)$ and EM fungi $(1-30 \%)$ in the nettle roots whereas EM fungi (26 - 75\%), mainly represented by Tomentella, Geopora, Hymenogaster,

372 Hebeloma and Clavulina genera, were the most abundant guild in poplar roots (Figure 4). This 373 guild was significantly more abundant in roots of Skado poplar, compared to I214 poplar (63\% 374 vs $26 \%$ for HTM area, $\mathrm{P}<0.05$; Figure 4). EM fungi were abundant on nettle roots and, for the 375 LTM area, even more on nettle grown with the Skado cultivar than on those grown with I214 $376(30 \%$ vs $2 \% ; \mathrm{P}<0.05)$. Endophytes were poorly represented in the poplar roots in contrast to 377 nettle $(0.1 \%$ vs. $9.2 \%$ of all sequences; $\mathrm{P}<0.05$; Figure 4$)$. Twelve OTUs assigned to AM fungi 378 were found in nettle and poplar roots, accounting for less than $0.05 \%$ of all sequences (not 379 shown). Plant pathogenic fungi were equally represented in poplar and nettle roots, without any 380 influence of the studied factors (Figure 4).

$381 \quad$ Functional guild also revealed several differences between soil contamination levels. 382 Indeed, the relative abundance of nettle saprotrophs was higher in the HTM area (statistically 383 supported only for the Skado plots; P < 0.05) (Figure 4). This result was driven by Kotlabaea, 384 the most abundant genus within this guild (Figure 3): an unidentified species from this genus, 385 accounting for $66 \%$ of all the saprotrophs associated with nettle, was indeed significantly more 386 present in the HTM areas $(\mathrm{P}<0.001)$. EM fungi associated with poplar (particularly Inocybe 387 and Tuber) and nettle (particularly Inocybe) tended to decrease in the HTM area, which was 388 statistically supported for I214 plot in the case of poplar $(75 \% v s 26 \%, \mathrm{P}<0.05)$ and for Skado 389 plot in the case of nettle $(30 \%$ vs $6 \%$; $>0.05$; Figure 4$)$. 

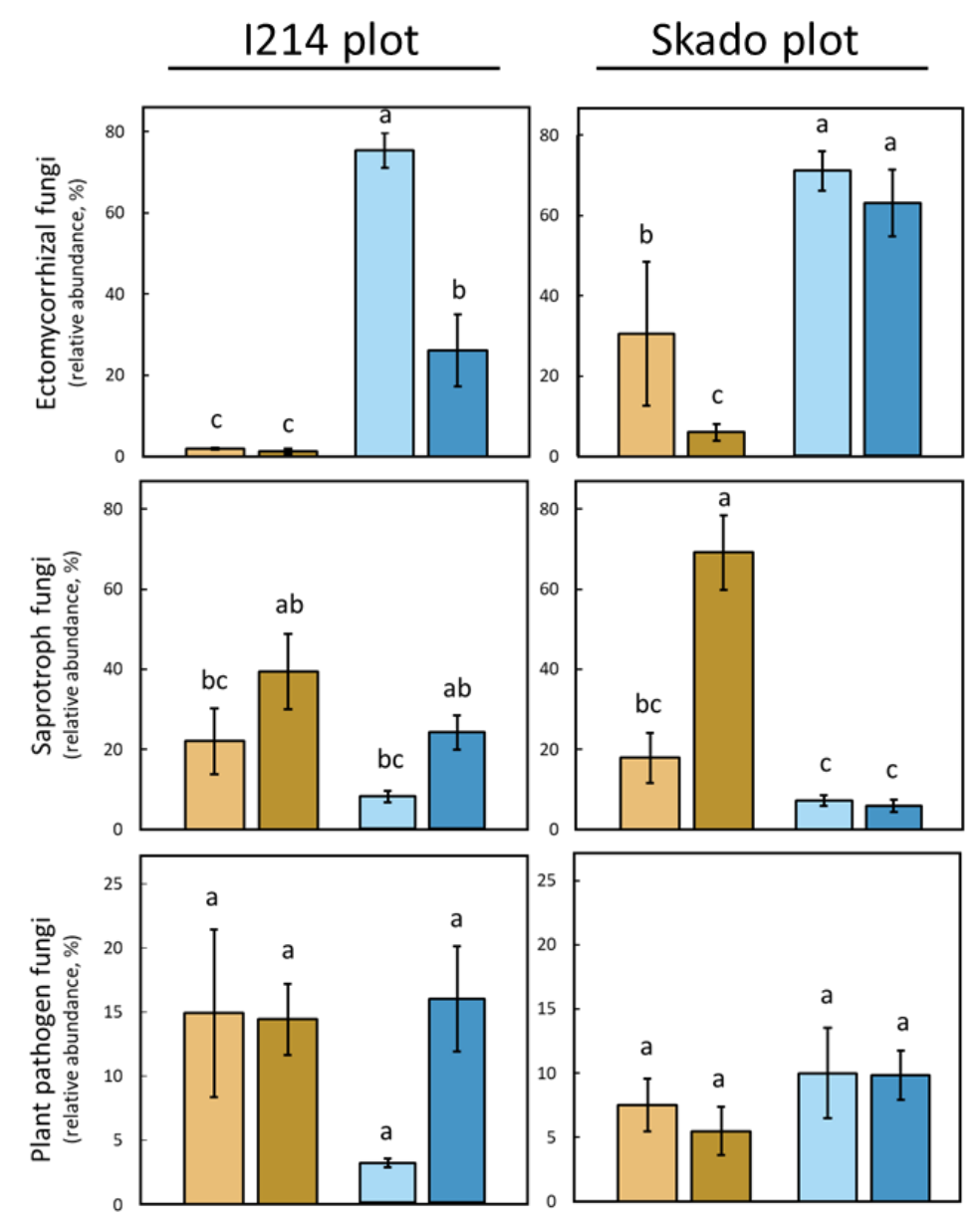

391 Figure 4: Relative abundance of the four most abundant fungal guilds associated with nettles 392 and poplars grown at the LTM or HTM area, for I214 (left) and Skado (right) plots. Data are 393 the means $\pm S E(n=6$ or 7$)$. For each class, bars designated with the same letter(s) are not significantly different (Kruskal-Wallis, $P<0.05$ ).

\subsection{Overlap of poplar and nettle microbial communities}

According to the Mantel test, nettle and poplar total fungal communities under I214 (P

$398<0.05)$ or Skado $(\mathrm{P}<0.01)$ plots were significantly correlated (Figure 5), while the

399 corresponding Morisita-Horn similarity index did not corroborate this result. However, similarity indexes and Mantel tests converged for nettle and poplar root-associated animal 
pathogenic fungi, EM fungi and saprotrophs that were significantly correlated (Mantel test, $\mathrm{P}<$

4020.05 ) and overlapped (Morisita-Horn index $<0.5$; Figure 5). Despite the low relative abundance

403 of EM fungi on nettle under I214 plots (Figure 4), nettle and poplar composition of EM fungi

404 were strongly correlated $(\mathrm{P}<0.001$, Figure 5$)$ for I214, while it was not the case for Skado

405 plots. Interestingly, the saprotrophic guild of the two plant species were only correlated and 406 overlapped at I214 plots, where the most abundant genera Kotlabaea was driving the trend.

407 Consequently, these results suggested that nettle and poplar roots shared large part of their 408 fungal communities.

Figure 5: Correlations (Mantel test) and similarity (Morisita-Horn index) between the OTUs composition of nettle and poplar, for the whole fungal community ("Total Fungi") and the six most abundant guilds depending on the poplar cultivar plot. The size of the circles is proportional to the P-value for the Mantel test and to the index value for Morisita-Horn. Two communities with a Morisita-Horn index $\geq 0.5$ are considered similar. P-value of the Mantel tests are represented with the following legend ${ }^{* *}, P<0.001$; **, $P<0.01$; $* P<0.05$. 
Although there was a significant relationship between EM fungi associated with the two

417 plants, the NMDS analysis showed that EM fungi of nettle and poplar clustered for each host,

418 but not together, suggesting host differentiation (Figure 6.A). EM fungi were significantly more represented $(59.6 \%$ vs 9.7\%; $\mathrm{P}<0.05)$ and diverse $(330 v s 146$ OTUs; $\mathrm{P}<0.05)$ in poplar than in nettle roots (Figure 4 and 6.C). Moreover, the ratios between nettle and poplar EM richnesses were similar for each condition (ranging from 0.64 to 0.83 ). A Venn diagram showed a higher species richness of EM fungi associated with poplar and particularly with the Skado cultivar (Figure 6.B), confirming poplar as the main host for EM fungi. As observed above for poplar, nettle EM fungi were more represented in terms of richness (115 vs 65 OTUs) and abundance (27.1 vs $1.7 \%$ of the total number of sequences) under the Skado plots as compared to the I214 plots. Among the 138 OTUs associated with nettle, 102 OTUs were shared between nettle and poplar (Figure 6.B). Only 29 of the 115 EM OTUs (representing $1.6 \%$ of the total abundance of EM fungi) under the Skado plots and 8 of the 65 EM OTUs (11.7\% of the total abundance) under the I214 plots were specific to nettle (Figure 6.B). These results suggested that most of the EM fungi associated with nettle were related to these hosted by poplar.
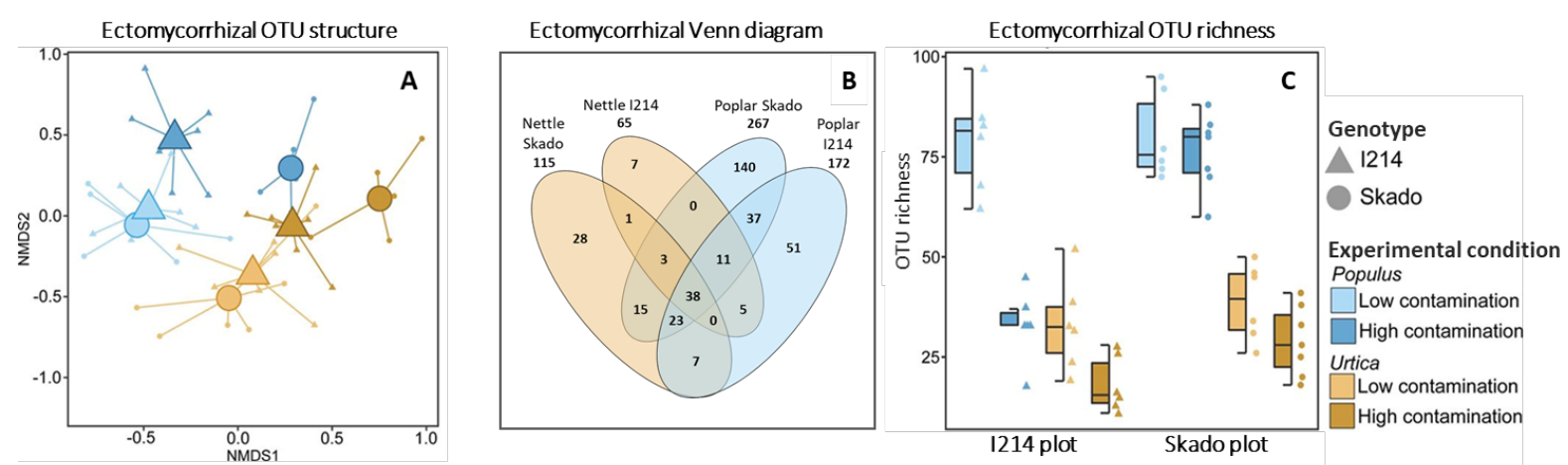

Figure 6: (A) Non-metric multidimensional scaling (NMDS) analysis of the EM fungal guild structure associated to poplar or nettle roots, (B) a Venn diagram based on EM OTUs and (C) the EM OTU richness, depending on the plant species (poplar or nettle), the poplar cultivar plot and the level of contamination (LTM and HTM). 
Helvella elastica, Inocybe semifulva, Clavulina sp. and Hebeloma eburneum (Figure S3). The

440 EM OTUs Geopora cervina and Tuber rapaeodorum were abundant in roots of poplar grown

441 at the HTM area (Figure S3). Most of these taxa were poorly represented in the nettle roots, 442 except for Inocybe rimosa, which was the most abundant EM fungus in both plants (Figure S3). 443 Indeed, this species accounted for $4 \%$ of nettle sequences (95\% from the Skado plots) and $444 \quad 12.3 \%$ of poplar sequences (52\% from the Skado plots). Additionally, this species was more 445 abundant in roots of nettle grown with the Skado cultivar $(\mathrm{P}<0.05)$, and when associated with 446 poplar, it was sensitive to the soil contamination $(\mathrm{P}<0.05)$ (Figure $\mathrm{S} 3)$.

\section{Discussion}

\subsection{EM fungi dominated the poplar mycobiome}

In this study, the mycobiome associated with poplar roots were clearly dominated by several EM fungal species, such as the Agaricomycetes Inocybe rimosa, Tomentella sp., and Hebeloma spp., and the Pezizomycetes Tuber rapeodorum and Geopora cervina. We also detected the presence of AM fungi belonging to the Rhizophagus and Glomus genera, although with a rather low number of sequences $(<0.001 \%)$, partially due to the choice that was made to target the ITS1 region, which is not the most adapted region for the study of Glomeromycota

Beeck et al., 2014). The recorded EM fungal species are known fungal symbionts of poplar (Podila et al., 2009) that improve plant health by enhancing resistance to diverse stresses like drought, salinity, heavy metals and pathogens, etc. (van der Heijden et al., 2015). Particularly, 459 they facilitate the adaptation of plants to TE stress, promoting host growth and 460 phytomanagement of TM-contaminated soils (Gil-Martínez et al., 2018). In a previous study on a $\mathrm{Hg}$-enriched sediment disposal site, the same experimental 462 design was set up in 2011. Durand et al. (2017) showed that EM fungi, and particularly the 463 Tuber and Geopora genera also dominated the roots of Skado poplar at this site. These taxa seemed to be largely abundant in TM contaminated sites (Bonito et al., 2014; Guevara et al., 
2013; Lacercat-Didier et al., 2016). Moreover, these EM fungi were not only related to the

466 physico-chemical properties of these sites, but rather to the juvenil tree stage that promotes some Pezizales (Geopora spp., Tuber spp.) or Agaricales (Inocybe spp.) (Foulon et al., 2016b; Hrynkiewicz et al., 2010; Lacercat-Didier et al., 2016). Hebeloma or Inocybe species, which were well represented at the studied site, are "early stage" fungi capable of colonizing roots of trees established in virgin or disturbed habitats (Smith and Read, 2010). In our dataset, only 7\%

471 of the variability were explained by the cultivar factor when performing a PERMANOVA on 472 the poplar dataset (data not shown), indicating that the mycobiomes of Skado and I214 roots 473 were comparable, consistently our previous results (Foulon et al., 2016a): in our previous work, 474 the mycobiome of eight poplar cultivars grown at a TM-contaminated site, exhibited slight 475 differences, especially between I214 and Skado roots. Together with the present study, the only 476 discrepancy between the two communities concerned the Laccaria genus, only recorded under 477 the I214 cultivar in small abundance. This similarity between the two studies might be linked 478 to the similar TM composition of the two sites and the similar age of the poplar plantation (7479 years in Foulon et al., (2016a) vs 6-years in the present study).

\subsection{Saprotroph and endophytic fungi dominated the nettle root mycobiome}

The overall fungal composition of nettle roots differed from that of poplar, despite their co-occurrence. Most of the dominant species associated with nettles were only assigned to the family or order level, reflecting a lack of information concerning the nettle mycobiome.

Dominant species on nettle roots were mostly endophytic or pathogenic fungi, such as Tetracladium sp., Olpidium spp., or saprotroph belonging to the Helotiales and Pleosporales 486 orders as previously observed for the non-mycorrhizal plant Arabis alpina (Almario et al., 487 2017). The most abundant OTU was assigned to the Kotlabaea genus, accounting for more than $48826 \%$ of all sequences. This species belongs to the Pyronemataceae, one of the largest family of 489 Pezizales traditionally considered saprotrophic, although the trophic strategies of most species 490 remain undocumented (Perry et al., 2007). Indeed, an increasing number of them are being 
identified as EM (Tedersoo et al., 2010). We classified Kotlabaea spp. as saprotrophic based

492 on (Tedersoo et al., 2014), but uncertainties remained. Overall, knowledge about taxonomy and

493 functional role of these root-associated fungi of nettle needs to be enriched by fungal isolation

494 and characterisation experiments, which has not yet been performed to our knowledge.

495

496

497

498

499

500

501

502

503

504

505

506

507

508

509

510

\subsection{The degree of contamination differently affected the mycobiomes of poplar and nettle}

According to a previous pedogeochemical characterization of the soils from the two areas, $\mathrm{Zn}$ and $\mathrm{Cd}$ concentrations were the most contrasted parameters between the two areas (Phanthavongsa et al., 2017). Other soil parameters were rather comparable, suggesting that the level of TM is one of the main factor influencing the soil fungal communities.

A slight reduction of fungal diversity was noticed for plants grown at the most contaminated area (HTM), which is commonly observed (Bååth, 1989; Giller et al., 2009). Indeed, while certain fungal microorganisms can tolerate large concentrations of non-essential heavy metals (e.g. Al, As, $\mathrm{Cd}, \mathrm{Hg}, \mathrm{Pb}$ ), plant mycobiome is generally affected (Gadd, 2010). Other studies showed that TM tended to reduce the amount of soil microbial biomass as well as the species richness, changing microbial structure in favor of tolerant taxa and modifying the soil functioning (Giller et al., 1998, 2009).

Some mycorrhizal fungi isolated from contaminated soils develop adaptations to tolerate metals (Colpaert et al., 2011; Gonçalves et al., 2009), which make them particularly suitable for phytomanagement applications. Indeed, plants inoculated with metal-tolerant EM fungi (Adriaensen et al., 2005; Redon et al., 2009) or DSE (Likar and Regvar, 2013) showed enhanced tolerance when compared to plants inoculated with non-tolerant strains. In our observations, Agaricomycetes, and particularly the Inocybe and Tomentella genera, when associated with nettle or poplar, were the most impacted by contamination. Although significantly reduced, these two EM fungi were still well represented at the heavily contaminated area on poplar roots. Additionally, the Inocybe genus has already been isolated 
517 (Repáč, 1996), and successfully tested as an inoculum strain on coniferous trees (Flores-

518 Rentería et al., 2018), which supports its interest in bioremediation applications. Their 519 usefulness and functional importance in nettle plantation deserves further analyses (see below).

520 In our study, members of the Pezizomycetes seemed to be the most tolerant fungi as the

521 Kotlabaea genus associated with nettle and the Tuber genus, associated with poplars, were more

522 represented in the area with the highest concentration of $\mathrm{Cd}, \mathrm{Zn}, \mathrm{Cu}$ and $\mathrm{Pb}$. This increase of

523 Perizomycetes related to soil contamination has already been detected in hydrocarbon-

524 contaminated soils (Bell et al., 2014; Tardif et al., 2016). Indeed, an untested possibility is that

525 hydrocarbons are also present at our site because canals dredged sediments generally contain

526 various contaminants (Besser et al., 1996; King et al., 2006).

\subsection{A significant fraction of EM fungi were shared by poplar and nettle roots}

Despite the noticeable differences mentioned above in terms of fungal composition between nettle and poplar, our results suggested that their respective mycobiome could be influenced by the other when co-occurring. More specifically, fungal taxa associated with abundant plants seemed more likely to colonize neighbouring plants than if the later were alone.

532 Indeed, taxa characteristics of the nettle mycobiome (e.g. Helvella, Kotlabaea) where more 533 represented in the $\mathrm{I} 214$ plot where nettle covered up to $60 \%$ of the herbaceous layer, compared 534 to the Skado plot where nettle and other plants were rare. Similarly, an influence of Skado 535 poplar on the mycobiome of neighbouring nettles was possibly detected, since a significant part $536(9.7 \%)$ of EM OTUs, which were characteristic of poplars mycobiomes, contributed to the 537 mycobiome of nettle roots, which might be surprising as this plant is a recognised non538 mycorrhizal plant (Vierheilig et al., 1996). Nettle roots were carefully washed and sorted, 539 making contaminations by the adjacent soil or poplar roots unlikely. Yet their presence on the 540 rhizoplane or as true endophytes (i.e. with root penetration) deserves further investigations. Indded, the ability of some EM fungi to colonize AM (and more generally non-EM) 542 plants has already been described for several clades based on molecular detection and direct 
543 observations, mainly for Sebacinaceae (Selosse et al., 2009; Weiß et al., 2011) and Tuber spp.

544 (Gryndler et al., 2014; Schneider-Maunoury et al., 2018, 2020). In addition, some suspicion exists, based on molecular detection only, for Thelephoraceae and Inocybaceae (SchneiderMaunoury et al., 2018, 2020), Pyronemataceae (Hansen et al., 2013) and Helotiales (Wang et al., 2006). Such a dual, EM and endophytic interaction has been viewed as a persistence of the evolutionary past of EM fungi, if they evolved from endophytic species: in the so-called 'waiting room hypothesis', endophytism is considered as a niche from which the tighter and more elaborate mycorrhizal symbiosis can evolve (Schneider-Maunoury et al., 2018; Selosse et al., 2009; van der Heijden et al., 2015). It was recently commentated that many fungi have more complex niches (e.g., dual niches) than what is commonly agreed, which could be explained by such evolutionary trajectories (Selosse et al., 2018, Thoen et al., 2020).

Recently, Taschen et al. (2020) demonstrated that Tuber melanosporum growth gains benefit from the non-EM plants it colonizes, while it has a negative effect on them. Additionally, the EM trees colonized by this fungus as ectomycorrhizal partners gain, at least in terms of nitrogen content, from the interaction between truffles and non-EM plants. The 558 possibility of an overlooked interaction between EM- and AM- or non-mycorrhizal plants 559 growing close to host trees is further supported by the fact that connection and the exchange of 560 carbon between plant sharing the same belowground ectomycorrhizal network were 561 demonstrated for trees (Klein et al., 2016; Selosse et al., 2006), even when one of the plant was 562 herbaceous (Selosse et al., 2009). The functional implications for plants of an extensive sharing 563 of non-mycorrhizal fungi remained unclear and highly dependant on the plant-fungus 564 association. In case they are beneficial, and this happens even for non-mycorrhizal endophytic 565 fungi such as dark septate endophytes in non-mycorrhizal plants (Liu et al., 2017; Yung et al., 566 2021), there may be mutual reinforcement of the two plant species by way of coordinated 567 responses to stresses, nutritional sharing, etc. Yet, the benefit can be asymmetric, or even 
relevant for one plant species only. Moreover, an intriguing possibility is pathogen spillover

569 (Mordecai, 2011), i.e. one plant promotes the spread of pathogens that harm competitors more strongly than itself. In this context, further investigations are now necessary to conclude about

571

572 the exact nature and functionality of this poplar-nettle EM sharing and its consequence for this agroforestry system.

Inocybe rimosa, the most abundant EM fungal species found on nettle roots, accounting for approximately $4 \%$ of the total fungal sequences, is a major candidate for such studies. The presence of I. rimosa is reported in TM-polluted soils (Huang et al., 2012; Krpata et al., 2009) and, although its ability to colonize roots of non-EM plant has not been previously investigated, Inocybaceae were already detected in some AM plants (Schneider-Maunoury et al., 2018). Any facilitation mechanism through EM fungi could contribute to the dominance of nettles within Salicaceous SRC in natural (Cronk et al., 2016) and contaminated sites (Yung et al., 2019). However, further research about the mycobiome of nettle roots and particularly in the case of co-cropping at phytomanagement sites, especially to assess morphological (e.g. by fluorescent in-situ hybridization; Schneider-Maunoury et al., 2020) and functional evidence of interactions with EM fungi, is now awaited. I. rimosa is present in the CBS Filamentous fungi and Yeast Collection as CBS 210.55. It will be used in further experiments, for poplar x nettle experiments to test its growth between the two plants and assess its positive or negative or no influence on nettle.

As a conclusion, we taxonomically and functionnaly characterized the fungal microbiomes of a spontaneous species (i.e., Urtica dioica L.) co-occuring with cultivated crops (i.e., Populus spp.) at a phytomanaged area contaminated with TM. Our results suggested that nettle and poplar had distinct root-associated fungal communities, albeit sharing many common ectomycorrhizal fungi and particularly the genus Inocybe, which is surprising given the nonmycorrhizal status of nettle. These results suggest to reconsider the ecological niches of fungi. 
594 The authors gratefully acknowledge the funding provided We thank VNF (Voies Navigables

595 de France) and Valérie Bert (INERIS) for providing us with access to the experimental site at

596 Fresnes-sur-Escaut.

\section{Funding sources}

598 This work was supported by ADEME, France, under grant No. 1772C0018, PHYTOFIBER

599 Project, by ANR, under grant n²010-INTB-1703- 03 BIOFILTREE (ANR Programme Blanc

600 International) and the Fondation de France and ADEME for their financial support to LY under

601 a PhD grant.

602

603

\section{References}

604

605

606

607

608

609

610

611

612

613

614

615

616

617

618

619

620

621

622

623

624

625

626

627

Adriaensen, K., Vrålstad, T., Noben, J.-P., Vangronsveld, J., Colpaert, J.V., 2005. Copper-adapted Suillus luteus, a symbiotic solution for pines colonizing $\mathrm{Cu}$ mine spoils. Appl. Environ. Microbiol. 71, 7279-7284. https://doi.org/10.1128/AEM.71.11.7279-7284.2005

Almario, J., Jeena, G., Wunder, J., Langen, G., Zuccaro, A., Coupland, G., Bucher, M., 2017. Rootassociated fungal microbiota of nonmycorrhizal Arabis alpina and its contribution to plant phosphorus nutrition. Proc. Natl. Acad. Sci. 114, E9403-E9412.

Bååth, E., 1989. Effects of heavy metals in soil on microbial processes and populations (a review). Water. Air. Soil Pollut. 47, 335-379. https://doi.org/10.1007/BF00279331

Bacci, L., Baronti, S., Predieri, S., di Virgilio, N., 2009. Fiber yield and quality of fiber nettle (Urtica dioica L.) cultivated in Italy. Ind. Crops Prod. 29, 480-484. https://doi.org/10.1016/j.indcrop.2008.09.005

Bainard, L.D., Navarro-Borrell, A., Hamel, C., Braun, K., Hanson, K., Gan, Y., 2017. Increasing the frequency of pulses in crop rotations reduces soil fungal diversity and increases the proportion of fungal pathotrophs in a semiarid agroecosystem. Agric. Ecosyst. Environ. 240, 206-214. https://doi.org/10.1016/j.agee.2017.02.020

Balabanova, B., Stafilov, T., Bačeva, K., 2015. Bioavailability and bioaccumulation characterization of essential and heavy metals contents in R. acetosa, S. oleracea and U. dioica from copper polluted and referent areas. J. Environ. Health Sci. Eng. 13. https://doi.org/10.1186/s40201-015-0159-1

Beeck, M.O.D., Lievens, B., Busschaert, P., Declerck, S., Vangronsveld, J., Colpaert, J.V., 2014. Comparison and Validation of Some ITS Primer Pairs Useful for Fungal Metabarcoding Studies. PLOS ONE 9, e97629. https://doi.org/10.1371/journal.pone.0097629

Bell, T.H., Hassan, S.E.-D., Lauron-Moreau, A., Al-Otaibi, F., Hijri, M., Yergeau, E., St-Arnaud, M., 2014. Linkage between bacterial and fungal rhizosphere communities in hydrocarbon-contaminated soils is related to plant phylogeny. ISME J. 8, 331-343. https://doi.org/10.1038/ismej.2013.149 
Besser, J.M., Giesy, J.P., Kubitz, J.A., Verbrugge, D.A., Coon, T.G., Emmett Braselton, W., 1996. Assessment of Sediment Quality in Dredged and Undredged Areas of the Trenton Channel of the Detroit River, Michigan USA, using the Sediment Quality Triad. J. Gt. Lakes Res. 22, 683-696. https://doi.org/10.1016/S0380-1330(96)70989-9

Boisson, S., Le Stradic, S., Collignon, J., Séleck, M., Malaisse, F., Ngoy Shutcha, M., Faucon, M.-P., Mahy, G., 2016. Potential of copper-tolerant grasses to implement phytostabilisation strategies on polluted soils in South D. R. Congo: Poaceae candidates for phytostabilisation. Environ. Sci. Pollut. Res. 23, 13693-13705. https://doi.org/10.1007/s11356-015-5442-2

Bonito, G., Reynolds, H., Robeson, M.S., Nelson, J., Hodkinson, B.P., Tuskan, G., Schadt, C.W., Vilgalys, R., 2014. Plant host and soil origin influence fungal and bacterial assemblages in the roots of woody plants. Mol. Ecol. 23, 3356-3370. https://doi.org/10.1111/mec.12821

Broekaert, W.F., VAN Parijs, J., Leyns, F., Joos, H., Peumans, W.J., 1989. A chitin-binding lectin from stinging nettle rhizomes with antifungal properties. Science 245, 1100-1102. https://doi.org/10.1126/science.245.4922.1100

Ciadamidaro, L., Girardclos, O., Bert, V., Zappelini, C., Yung, L., Foulon, J., Papin, A., Roy, S., Blaudez, D., Chalot, M., 2017. Poplar biomass production at phytomanagement sites is significantly enhanced by mycorrhizal inoculation. Environ. Exp. Bot. 139, 48-56. https://doi.org/10.1016/j.envexpbot.2017.04.004

Colpaert, J.V., Wevers, J.H.L., Krznaric, E., Adriaensen, K., 2011. How metal-tolerant ecotypes of ectomycorrhizal fungi protect plants from heavy metal pollution. Ann. For. Sci. 68, 17-24. https://doi.org/10.1007/s13595-010-0003-9

Cronk, Q., Hidalgo, O., Pellicer, J., Percy, D., Leitch, I., 2016. Salix transect of Europe: variation in ploidy and genome size in willow-associated common nettle, Urtica dioica L. sens. lat., from Greece to arctic Norway. Biodivers. Data J. 4, e10003. https://doi.org/10.3897/BDJ.4.e10003

Cundy, A.B., Bardos, R.P., Puschenreiter, M., Mench, M., Bert, V., Friesl-Hanl, W., Müller, I., Li, X.N., Weyens, N., Witters, N., Vangronsveld, J., 2016. Brownfields to green fields: Realising wider benefits from practical contaminant phytomanagement strategies. J. Environ. Manage. 184, 67-77. https://doi.org/10.1016/j.jenvman.2016.03.028

Deng, Z., Cao, L., 2017. Fungal endophytes and their interactions with plants in phytoremediation: A review. Chemosphere 168, 1100-1106. https://doi.org/10.1016/j.chemosphere.2016.10.097

Di Virgilio, N., Papazoglou, E.G., Jankauskiene, Z., Di Lonardo, S., Praczyk, M., Wielgusz, K., 2015. The potential of stinging nettle (Urtica dioica L.) as a crop with multiple uses. Ind. Crops Prod. 68, 42-49. https://doi.org/10.1016/j.indcrop.2014.08.012

Durand, A., Maillard, F., Foulon, J., Gweon, H.S., Valot, B., Chalot, M., 2017. Environmental Metabarcoding Reveals Contrasting Belowground and Aboveground Fungal Communities from Poplar at a Hg Phytomanagement Site. Microb. Ecol. https://doi.org/10.1007/s00248-017-0984-0

Evangelou, M.W.H., Papazoglou, E.G., Robinson, B.H., Schulin, R., 2015. Phytomanagement: Phytoremediation and the Production of Biomass for Economic Revenue on Contaminated Land, in: Ansari, A.A., Gill, S.S., Gill, R., Lanza, G.R., Newman, L. (Eds.), Phytoremediation. Springer International Publishing, Cham, pp. 115-132. https://doi.org/10.1007/978-3-319-10395-2_9

Flores-Rentería, D., Barradas, V.L., Álvarez-Sánchez, J., 2018. Ectomycorrhizal pre-inoculation of Pinus hartwegii and Abies religiosa is replaced by native fungi in a temperate forest of central Mexico. Symbiosis 74, 131-144. https://doi.org/10.1007/s13199-017-0498-z

Fontenla, S., García-Romera, I., Ocampo, J.A., 1999. Negative influence of non-host plants on the colonization of Pisum sativum by the arbuscular mycorrhizal fungus Glomus mosseae. Soil Biol. Biochem. 31, 1591-1597. https://doi.org/10.1016/S0038-0717(99)00087-5

Foulon, J., Zappelini, C., Durand, A., Valot, B., Blaudez, D., Chalot, M., 2016a. Impact of poplar-based phytomanagement on soil properties and microbial communities in a metal-contaminated site. FEMS Microbiol. Ecol. 92. https://doi.org/10.1093/femsec/fiw163 
Foulon, J., Zappelini, C., Durand, A., Valot, B., Girardclos, O., Blaudez, D., Chalot, M., $2016 \mathrm{~b}$. Environmental metabarcoding reveals contrasting microbial communities at two poplar $\begin{array}{llllll}\text { phytomanagement } & \text { sites. } & \text { Sci. Total Environ. 571, 1230-1240. }\end{array}$ https://doi.org/10.1016/j.scitotenv.2016.07.151

Gadd, G.M., 2010. Metals, minerals and microbes: geomicrobiology and bioremediation. Microbiology 156, 609-643. https://doi.org/10.1099/mic.0.037143-0

Gardes, M., Bruns, T.D., 1993. ITS primers with enhanced specificity for basidiomycetes--application to the identification of mycorrhizae and rusts. Mol. Ecol. 2, 113-118. https://doi.org/10.1111/j.1365294x.1993.tb00005.x

Gehring, C.A., Mueller, R.C., Whitham, T.G., 2006. Environmental and genetic effects on the formation of ectomycorrhizal and arbuscular mycorrhizal associations in cottonwoods. Oecologia 149, 158164. https://doi.org/10.1007/s00442-006-0437-9

Gerhardt, K.E., Gerwing, P.D., Greenberg, B.M., 2017. Opinion: Taking phytoremediation from proven technology to accepted practice. Plant Sci. 256, 170-185. https://doi.org/10.1016/j.plantsci.2016.11.016

Giller, K.E., Witter, E., McGrath, S.P., 2009. Heavy metals and soil microbes. Soil Biol. Biochem. 41, 2031-2037. https://doi.org/10.1016/j.soilbio.2009.04.026

Giller, K.E., Witter, E., Mcgrath, S.P., 1998. Toxicity of heavy metals to microorganisms and microbial processes in agricultural soils: a review. Soil Biol. Biochem. 30, 1389-1414. https://doi.org/10.1016/S0038-0717(97)00270-8

Gil-Martínez, M., López-García, Á., Domínguez, M.T., Navarro-Fernández, C.M., Kjøller, R., Tibbett, M., Marañón, T., 2018. Ectomycorrhizal Fungal Communities and Their Functional Traits Mediate Plant-Soil Interactions in Trace Element Contaminated Soils. Front. Plant Sci. 9. https://doi.org/10.3389/fpls.2018.01682

Gonçalves, S.C., Martins-Loução, M.A., Freitas, H., 2009. Evidence of adaptive tolerance to nickel in isolates of Cenococcum geophilum from serpentine soils. Mycorrhiza 19, 221-230. https://doi.org/10.1007/s00572-008-0211-4

Good, I.J., 1953. The Population Frequencies of Species and the Estimation of Population Parameters. Biometrika 40, 237-264. https://doi.org/10.2307/2333344

Gryndler, M., Černá, L., Bukovská, P., Hršelová, H., Jansa, J., 2014. Tuber aestivum association with non-host roots. Mycorrhiza 24, 603-610. https://doi.org/10.1007/s00572-014-0580-9

Guevara, G., Bonito, G., Trappe, J.M., Cázares, E., Williams, G., Healy, R.A., Schadt, C., Vigalys, R., 2013. New North American truffles (Tuber spp.) and their ectomycorrhizal associations. Mycol. 1051 194-209 105, 194-209. https://doi.org/10.3852/12-087

Hansen, K., Perry, B.A., Dranginis, A.W., Pfister, D.H., 2013. A phylogeny of the highly diverse cupfungus family Pyronemataceae (Pezizomycetes, Ascomycota) clarifies relationships and evolution of selected life history traits. Mol. Phylogenet. Evol. 67, 311-335. https://doi.org/10.1016/j.ympev.2013.01.014

Hrynkiewicz, K., Baum, C., Leinweber, P., Weih, M., Dimitriou, I., 2010. The significance of rotation periods for mycorrhiza formation in Short Rotation Coppice. For. Ecol. Manag. 260, 1943-1949. https://doi.org/10.1016/j.foreco.2010.08.020

Huang, J., Nara, K., Lian, C., Zong, K., Peng, K., Xue, S., Shen, Z., 2012. Ectomycorrhizal fungal communities associated with Masson pine (Pinus massoniana Lamb.) in $\mathrm{Pb}-\mathrm{Zn}$ mine sites of central south China. Mycorrhiza 22, 589-602. https://doi.org/10.1007/s00572-012-0436-0

Huang, X., Liu, S., Liu, X., Zhang, S., Li, L., Zhao, H., Zhao, J., Zhang, J., Cai, Z., 2020. Plant pathological condition is associated with fungal community succession triggered by root exudates in the plant-soil system. Soil Biol. Biochem. 151, 108046. https://doi.org/10.1016/j.soilbio.2020.108046

James, D.G., Lauby, G., Seymour, L., Buckley, K., 2015. Beneficial insects associated with stinging nettle, Urtica dioica Linnaeus, in central Washington State. Pan-Pac. Entomol. 91, 82-90. 
Jeannin, T., Yung, L., Evon, P., Labonne, L., Ouagne, P., Lecourt, M., Cazaux, D., Chalot, M., Placet, V., 2020. Are nettle fibers produced on metal-contaminated lands suitable for composite applications? Mater. Today Proc. https://doi.org/10.1016/j.matpr.2020.01.365

Jeannin, T., Yung, L., Evon, P., Labonne, L., Ouagne, P., Lecourt, M., Cazaux, D., Chalot, M., Placet, V., 2019. Native stinging nettle (Urtica dioica L.) growing spontaneously under short rotation coppice for phytomanagement of trace element contaminated soils: Fibre yield, processability and quality. Ind. Crops Prod. 111997. https://doi.org/10.1016/j.indcrop.2019.111997

Khan, A.G., 2005. Role of soil microbes in the rhizospheres of plants growing on trace metal contaminated soils in phytoremediation. J. Trace Elem. Med. Biol. 18, 355-364. https://doi.org/10.1016/j.jtemb.2005.02.006

Kidd, P., Mench, M., Álvarez-López, V., Bert, V., Dimitriou, I., Friesl-Hanl, W., Herzig, R., Janssen, J.O., Kolbas, A., Müller, I., Neu, S., Renella, G., Ruttens, A., Vangronsveld, J., Puschenreiter, M., 2015. Agronomic Practices for Improving Gentle Remediation of Trace Element-Contaminated Soils. Int. J. Phytoremediation 17, 1005-1037. https://doi.org/10.1080/15226514.2014.1003788

King, R.F., Royle, A., Putwain, P.D., Dickinson, N.M., 2006. Changing contaminant mobility in a dredged canal sediment during a three-year phytoremediation trial. Environ. Pollut. Barking Essex 1987 143, 318-326. https://doi.org/10.1016/j.envpol.2005.11.024

Klein, T., Siegwolf, R.T.W., Körner, C., 2016. Belowground carbon trade among tall trees in a temperate forest. Science 352, 342-344. https://doi.org/10.1126/science.aad6188

Kõljalg, U., Nilsson, R.H., Abarenkov, K., Tedersoo, L., Taylor, A.F.S., Bahram, M., Bates, S.T., Bruns, T.D., Bengtsson-Palme, J., Callaghan, T.M., Douglas, B., Drenkhan, T., Eberhardt, U., Dueñas, M., Grebenc, T., Griffith, G.W., Hartmann, M., Kirk, P.M., Kohout, P., Larsson, E., Lindahl, B.D., Lücking, R., Martín, M.P., Matheny, P.B., Nguyen, N.H., Niskanen, T., Oja, J., Peay, K.G., Peintner, U., Peterson, M., Põldmaa, K., Saag, L., Saar, I., Schüßler, A., Scott, J.A., Senés, C., Smith, M.E., Suija, A., Taylor, D.L., Telleria, M.T., Weiss, M., Larsson, K.-H., 2013. Towards a unified paradigm for sequence-based identification of fungi. Mol. Ecol. 22, 5271-5277. https://doi.org/10.1111/mec.12481

Krpata, D., Fitz, W., Peintner, U., Langer, I., Schweiger, P., 2009. Bioconcentration of zinc and cadmium in ectomycorrhizal fungi and associated aspen trees as affected by level of pollution. Environ. Pollut. Barking Essex 1987 157, 280-286. https://doi.org/10.1016/j.envpol.2008.06.038

Lacercat-Didier, L., Berthelot, C., Foulon, J., Errard, A., Martino, E., Chalot, M., Blaudez, D., 2016. New mutualistic fungal endophytes isolated from poplar roots display high metal tolerance. Mycorrhiza 26, 657-671. https://doi.org/10.1007/s00572-016-0699-y

Likar, M., Regvar, M., 2013. Isolates of dark septate endophytes reduce metal uptake and improve physiology of Salix caprea L. Plant Soil 370, 593-604. https://doi.org/10.1007/s11104-013-1656-6

Liu, H., Li, T., Ding, Y., Yang, Y., Zhao, Z., 2017. Dark septate endophytes colonizing the roots of 'non-mycorrhizal' plants in a mine tailing pond and in a relatively undisturbed environment, Southwest China. J. Plant Interact. 12, 264-271. https://doi.org/10.1080/17429145.2017.1333635

Ma, Y., Rajkumar, M., Oliveira, R.S., Zhang, C., Freitas, H., 2019. Potential of plant beneficial bacteria and arbuscular mycorrhizal fungi in phytoremediation of metal-contaminated saline soils. J. Hazard. Mater. 379, 120813. https://doi.org/10.1016/j.jhazmat.2019.120813

Macnair, M.R., 1987. Heavy metal tolerance in plants: A model evolutionary system. Trends Ecol. Evol. 2, 354-359. https://doi.org/10.1016/0169-5347(87)90135-2

Mahé, F., Rognes, T., Quince, C., Vargas, C. de, Dunthorn, M., 2015. Swarm v2: highly-scalable and high-resolution amplicon clustering. PeerJ 3, e1420. https://doi.org/10.7717/peerj.1420

Miransari, M., 2017. Arbuscular Mycorrhizal Fungi and Heavy Metal Tolerance in Plants, in: Wu, Q.S. (Ed.), Arbuscular Mycorrhizas and Stress Tolerance of Plants. Springer Singapore, Singapore, pp. 147-161. https://doi.org/10.1007/978-981-10-4115-0_7

Mordecai, E.A., 2011. Pathogen impacts on plant communities: unifying theory, concepts, and empirical work. Ecol. Monogr. 81, 429-441. https://doi.org/https://doi.org/10.1890/10-2241.1 
Murtic, S., Jurkovic, J., Basic, E., Hekic, E., 2019. Assessment of wild plants for phytoremediation of heavy metals in soils surrounding the thermal power station.

Nguyen, N.H., Song, Z., Bates, S.T., Branco, S., Tedersoo, L., Menke, J., Schilling, J.S., Kennedy, P.G., 2016. FUNGuild: An open annotation tool for parsing fungal community datasets by ecological guild. Fungal Ecol. 20, 241-248. https://doi.org/10.1016/j.funeco.2015.06.006

Otero-Blanca, A., Folch-Mallol, J.L., Lira-Ruan, V., del Rayo Sánchez Carbente, M., Batista-García, R.A., 2018. Phytoremediation and Fungi: An Underexplored Binomial, in: Prasad, R., Aranda, E. (Eds.), Approaches in Bioremediation: The New Era of Environmental Microbiology and Nanobiotechnology, Nanotechnology in the Life Sciences. Springer International Publishing, Cham, pp. 79-95. https://doi.org/10.1007/978-3-030-02369-0_5

Pandey, V.C., Bajpai, O., Singh, N., 2016. Energy crops in sustainable phytoremediation. Renew. Sustain. Energy Rev. 54, 58-73. https://doi.org/10.1016/j.rser.2015.09.078

Parraga-Aguado, I., Gonzalez-Alcaraz, M.N., Alvarez-Rogel, J., Jimenez-Carceles, F.J., Conesa, H.M., 2013. The importance of edaphic niches and pioneer plant species succession for the phytomanagement of mine tailings. Environ. Pollut. 176, 134-143. https://doi.org/10.1016/j.envpol.2013.01.023

Parraga-Aguado, I., Querejeta, J.-I., González-Alcaraz, M.-N., Jiménez-Cárceles, F.J., Conesa, H.M., 2014. Usefulness of pioneer vegetation for the phytomanagement of metal(loid)s enriched tailings: Grasses vs. shrubs vs. trees. J. Environ. Manage. 133, 51-58. https://doi.org/10.1016/j.jenvman.2013.12.001

Paukszto, A., Mirosławski, J., 2019. Using stinging nettle (Urtica dioica L.) to assess the influence of long term emission upon pollution with metals of the Tatra National Park area (Poland). Atmospheric Pollut. Res. 10, 73-79. https://doi.org/10.1016/j.apr.2018.06.004

Pepper, I.L., Gerba, C.P., Gentry, T.J. (Eds.), 2015. Environmental microbiology, Third edition. ed. Elsevier/AP, Academic Press is an imprint of Elsevier, Amsterdam.

Perrin, R.M., 1975. The role of the perennial stinging nettle, Urtica dioica, as a reservoir of beneficial natural enemies. Ann. Appl. Biol. 81, 289-297.

Perry, B.A., Hansen, K., Pfister, D.H., 2007. A phylogenetic overview of the family Pyronemataceae (Ascomycota, Pezizales). Mycol. Res. 111, 549-571. https://doi.org/10.1016/j.mycres.2007.03.014

Phanthavongsa, P., Chalot, M., Papin, A., Lacercat-Didier, L., Roy, S., Blaudez, D., Bert, V., 2017. Effect of mycorrhizal inoculation on metal accumulation by poplar leaves at phytomanaged sites. Environ. Exp. Bot. 143, 72-81. https://doi.org/10.1016/j.envexpbot.2017.08.012

Podila, G.K., Sreedasyam, A., Muratet, M.A., 2009. Populus Rhizosphere and the Ectomycorrhizal Interactome. Crit. Rev. Plant Sci. 28, 359-367. https://doi.org/10.1080/07352680903241220

Redon, P.-O., Béguiristain, T., Leyval, C., 2009. Differential effects of AM fungal isolates on Medicago truncatula growth and metal uptake in a multimetallic $(\mathrm{Cd}, \mathrm{Zn}, \mathrm{Pb})$ contaminated agricultural soil. Mycorrhiza 19, 187-195. https://doi.org/10.1007/s00572-009-0230-9

Repáč, I., 1996. Inoculation of Picea abies (L.) Karst. seedlings with vegetative inocula of ectomycorrhizal fungi Suillus bovinus (L.: Fr.) O. Kuntze and Inocybe lacera (Fr.) Kumm. New For. 12, 41-54. https://doi.org/10.1007/BF00029981

Schloss, P.D., Westcott, S.L., Ryabin, T., Hall, J.R., Hartmann, M., Hollister, E.B., Lesniewski, R.A., Oakley, B.B., Parks, D.H., Robinson, C.J., Sahl, J.W., Stres, B., Thallinger, G.G., Horn, D.J.V., Weber, C.F., 2009. Introducing mothur: Open-Source, Platform-Independent, CommunitySupported Software for Describing and Comparing Microbial Communities. Appl. Environ. Microbiol. 75, 7537-7541. https://doi.org/10.1128/AEM.01541-09

Schmidt, C.S., Lovecká, P., Mrnka, L., Vychodilová, A., Strejček, M., Fenclová, M., Demnerová, K., 2018. Distinct Communities of Poplar Endophytes on an Unpolluted and a Risk Element-Polluted Site and Their Plant Growth-Promoting Potential In Vitro. Microb. Ecol. 75, 955-969. https://doi.org/10.1007/s00248-017-1103-y 
Schneider-Maunoury, L., Deveau, A., Moreno, M., Todesco, F., Belmondo, S., Murat, C., Courty, P.E., Jąkalski, M., Selosse, M.-A., 2020. Two ectomycorrhizal truffles, Tuber melanosporum and T. aestivum, endophytically colonise roots of non-ectomycorrhizal plants in natural environments. New Phytol. 225, 2542-2556. https://doi.org/10.1111/nph.16321

Schneider-Maunoury, L., Leclercq, S., Clément, C., Covès, H., Lambourdière, J., Sauve, M., Richard, F., Selosse, M.-A., Taschen, E., 2018. Is Tuber melanosporum colonizing the roots of herbaceous, non-ectomycorrhizal plants? Fungal Ecol. 31, 59-68. https://doi.org/10.1016/j.funeco.2017.10.004

Selosse, M.-A., Baudoin, E., Vandenkoornhuyse, P., 2004. Symbiotic microorganisms, a key for ecological success and protection of plants. C. R. Biol. 327, 639-648. https://doi.org/10.1016/j.crvi.2003.12.008

Selosse, M.-A., Dubois, M.-P., Alvarez, N., 2009. Do Sebacinales commonly associate with plant roots as endophytes? Mycol. Res. 113, 1062-1069. https://doi.org/10.1016/j.mycres.2009.07.004

Selosse, M.-A., Jacquot, D., Bouchard, D., Martin, F., Tacon, F.L., 1998. Temporal persistence and spatial distribution of an American inoculant strain of the ectomycorrhizal basidiomycete Laccaria bicolor in a French forest plantation. Mol. Ecol. 7, 561-573. https://doi.org/10.1046/j.1365294x.1998.00353.x

Selosse, M.-A., Martin, F., Bouchard, D., le Tacon, F., 1999. Structure and Dynamics of Experimentally Introduced and Naturally Occurring Laccaria sp. Discrete Genotypes in a Douglas Fir Plantation. Appl. Environ. Microbiol. 65, 2006-2014.

Selosse, M.-A., Richard, F., He, X., Simard, S.W., 2006. Mycorrhizal networks: des liaisons dangereuses? Trends Ecol. Evol. 21, 621-628. https://doi.org/10.1016/j.tree.2006.07.003

Selosse, M.-A., Schneider-Maunoury, L., Martos, F., 2018. Time to re-think fungal ecology? Fungal ecological niches are often prejudged. New Phytol. 217, 968-972. https://doi.org/10.1111/nph.14983

Shams, K.M., Tichy, G., Fischer, A., Sager, M., Peer, T., Bashar, A., Filip, K., 2010. Aspects of phytoremediation for chromium contaminated sites using common plants Urtica dioica, Brassica napus and Zea mays. Plant Soil 328, 175-189. https://doi.org/10.1007/s11104-009-0095-x

Smith, S.E., Read, D.J., 2010. Mycorrhizal Symbiosis. Academic Press.

Tardif, S., Yergeau, É., Tremblay, J., Legendre, P., Whyte, L.G., Greer, C.W., 2016. The Willow Microbiome Is Influenced by Soil Petroleum-Hydrocarbon Concentration with Plant CompartmentSpecific Effects. Front. Microbiol. 7. https://doi.org/10.3389/fmicb.2016.01363

Taschen, E., Sauve, M., Vincent, B., Parladé, J., van Tuinen, D., Aumeeruddy-Thomas, Y., Assenat, B., Selosse, M.-A., Richard, F., 2020. Insight into the truffle brûlé: tripartite interactions between the black truffle (Tuber melanosporum), holm oak (Quercus ilex) and arbuscular mycorrhizal plants. Plant Soil 446, 577-594. https://doi.org/10.1007/s11104-019-04340-2

Tedersoo, L., Bahram, M., Põlme, S., Kõljalg, U., Yorou, N.S., Wijesundera, R., Villarreal Ruiz, L., Vasco-Palacios, A.M., Thu, P.Q., Suija, A., Smith, M.E., Sharp, C., Saluveer, E., Saitta, A., Rosas, M., Riit, T., Ratkowsky, D., Pritsch, K., Põldmaa, K., Piepenbring, M., Phosri, C., Peterson, M., Parts, K., Pärtel, K., Otsing, E., Nouhra, E., Njouonkou, A.L., Nilsson, R.H., Morgado, L.N., Mayor, J., May, T.W., Majuakim, L., Lodge, D.J., Lee, S.S., Larsson, K.-H., Kohout, P., Hosaka, K., Hiiesalu, I., Henkel, T.W., Harend, H., Guo, L., Greslebin, A., Grelet, G., Geml, J., Gates, G., Dunstan, W., Dunk, C., Drenkhan, R., Dearnaley, J., De Kesel, A., Dang, T., Chen, X., Buegger, F., Brearley, F.Q., Bonito, G., Anslan, S., Abell, S., Abarenkov, K., 2014. Fungal biogeography. Global diversity and geography of soil fungi. Science 346, 1256688. https://doi.org/10.1126/science.1256688

Tedersoo, L., May, T.W., Smith, M.E., 2010. Ectomycorrhizal lifestyle in fungi: global diversity, distribution, and evolution of phylogenetic lineages. Mycorrhiza 20, 217-263. https://doi.org/10.1007/s00572-009-0274-x

Teste, F.P., Jones, M.D., Dickie, I.A., 2020. Dual-mycorrhizal plants: their ecology and relevance. New Phytol. 225, 1835-1851. https://doi.org/10.1111/nph.16190 
Thoen, E., Harder, C.B., Kauserud, H., Botnen, S.S., Vik, U., Taylor, A.F.S., Menkis, A., Skrede, I., 2020. In vitro evidence of root colonization suggests ecological versatility in the genus Mycena. New Phytol. 227, 601-612. https://doi.org/https://doi.org/10.1111/nph.16545

Toju, H., Tanabe, A.S., Yamamoto, S., Sato, H., 2012. High-Coverage ITS Primers for the DNA-Based Identification of Ascomycetes and Basidiomycetes in Environmental Samples. PLOS ONE 7, e40863. https://doi.org/10.1371/journal.pone.0040863

van der Heijden, M.G.A., Martin, F.M., Selosse, M.-A., Sanders, I.R., 2015. Mycorrhizal ecology and evolution: the past, the present, and the future. New Phytol. 205, 1406-1423. https://doi.org/10.1111/nph.13288

Vierheilig, H., Iseli, B., Alt, M., Raikhel, N., Wiemken, A., Boller, T., 1996. Resistance ofUrtica dioica to mycorrhizal colonization: a possible involvement ofUrtica dioica agglutinin. Plant Soil 183, 131136.

Viktorova, J., Jandova, Z., Madlenakova, M., Prouzova, P., Bartunek, V., Vrchotova, B., Lovecka, P., Musilova, L., Macek, T., 2016. Native Phytoremediation Potential of Urtica dioica for Removal of PCBs and Heavy Metals Can Be Improved by Genetic Manipulations Using Constitutive CaMV 35S Promoter. PLoS ONE 11. https://doi.org/10.1371/journal.pone.0167927

Vitali, F., Raio, A., Sebastiani, F., Cherubini, P., Cavalieri, D., Cocozza, C., 2019. Environmental pollution effects on plant microbiota: the case study of poplar bacterial-fungal response to silver nanoparticles. Appl. Microbiol. Biotechnol. 103, 8215-8227. https://doi.org/10.1007/s00253-01910071-2

Wang, Q., Garrity, G.M., Tiedje, J.M., Cole, J.R., 2007. Naïve Bayesian Classifier for Rapid Assignment of rRNA Sequences into the New Bacterial Taxonomy. Appl. Environ. Microbiol. 73, 5261-5267. https://doi.org/10.1128/AEM.00062-07

Wang, X.-C., Liu, C., Huang, L., Bengtsson-Palme, J., Chen, H., Zhang, J.-H., Cai, D., Li, J.-Q., 2015. ITS1: a DNA barcode better than ITS2 in eukaryotes? Mol. Ecol. Resour. 15, 573-586. https://doi.org/10.1111/1755-0998.12325

Wang, Z.J., Johnston, P.R., Takamatsu, S., Spatafora, J.W., Hibbett, D.S., 2006. Toward a phylogenetic classification of the leotiomycetes based on rDNA data. undefined.

Weiß, M., Sýkorová, Z., Garnica, S., Riess, K., Martos, F., Krause, C., Oberwinkler, F., Bauer, R., Redecker, D., 2011. Sebacinales Everywhere: Previously Overlooked Ubiquitous Fungal Endophytes. PLOS ONE 6, e16793. https://doi.org/10.1371/journal.pone.0016793

Wilson, D., 1995. Endophyte: The Evolution of a Term, and Clarification of Its Use and Definition. Oikos 73, 274-276. https://doi.org/10.2307/3545919

White, T.J., Bruns, T., Lee, S., Taylor, J., 1990. 38 - Amplification and direct sequencing of fungal ribosomal rna genes for phylogenetics, in: Innis, M.A., Gelfand, D.H., Sninsky, J.J., White, T.J. (Eds.), PCR Protocols. Academic Press, San Diego, pp. 315-322. https://doi.org/10.1016/B978-0$12-372180-8.50042-1$

Wubs, E.R.J., Putten, W.H. van der, Bosch, M., Bezemer, T.M., 2016. Soil inoculation steers restoration of terrestrial ecosystems. Nat. Plants 2, 1-5. https://doi.org/10.1038/nplants.2016.107

Yung, L., Bertheau, C., Cazaux, D., Regier, N., Slaveykova, V.I., Chalot, M., 2019. Insect Life Traits Are Key Factors in Mercury Accumulation and Transfer within the Terrestrial Food Web. Environ. Sci. Technol. https://doi.org/10.1021/acs.est.9b04102

Yung, L., Blaudez, D., Maurice, N., Azou-Barré, A., Sirguey, C., 2021. Dark septate endophytes isolated from non-hyperaccumulator plants can increase phytoextraction of $\mathrm{Cd}$ and $\mathrm{Zn}$ by the hyperaccumulator Noccaea caerulescens. Environ. Sci. Pollut. Res. https://doi.org/10.1007/s11356020-11793-x

Zappelini, C., Karimi, B., Foulon, J., Lacercat-Didier, L., Maillard, F., Valot, B., Blaudez, D., Cazaux, D., Gilbert, D., Yergeau, E., Greer, C., Chalot, M., 2015. Diversity and complexity of microbial communities from a chlor-alkali tailings dump. Soil Biol. Biochem. 90, 101-110. https://doi.org/10.1016/j.soilbio.2015.08.008 